University of Zurich

Department of Economics

Working Paper Series

ISSN 1664-7041 (print)

ISSN 1664-705X (online)

Working Paper No. 48

Financial Incentives, the Timing of Births, Birth Complications, and Newborns' Health: Evidence from the Abolition of Austria's Baby Bonus

Beatrice Brunner and Andreas Kuhn

November 2011 


\title{
Financial Incentives, the Timing of Births, Birth Complications, and Newborns' Health: Evidence from the Abolition of Austria's Baby Bonus
}

\author{
Beatrice Brunner, University of Zurich* \\ Andreas Kuhn, University of Zurich and IZA
}

November 2011

\begin{abstract}
We analyze the fertility and health effects resulting from the abolition of the Austrian baby bonus in January 1997. The abolition of the benefit was publicly announced about ten months in advance, creating the opportunity for prospective parents to (re-)schedule conceptions accordingly. We find robust evidence that, within the month before the abolition, about $8 \%$ more children were born as a result of (re-)scheduling conceptions. At the same time, there is no evidence that mothers deliberately manipulated the date of birth through medical intervention. We also find a substantial and significant increase in the fraction of birth complications, but no evidence for any resulting adverse effects on newborns' health.
\end{abstract}

JEL classification: H31; J13

Keywords: baby bonus; scheduling of conceptions; timing of births; policy announcement; abolition effect; birth complications; medical intervention

${ }^{*}$ We thank Christian Dustmann, Rafael Lalive, Josef Zweimüller, as well as seminar participants in Brixen, Engelberg and Zurich for helpful comments and suggestions. We also thank Sandro Favre and Philippe Ruh for great research assistance. Financial support by the Austrian Science Fund ("The Austrian Center for Labor Economics and the Analysis of the Welfare State") is gratefully acknowledged.

Contact: University of Zurich, Department of Economics, Mühlebachstrasse 86, 8008 Zurich, Switzerland; beatrice.brunner@econ.uzh.ch; andreas.kuhn@econ.uzh.ch. 


\section{Introduction}

Considering the recent introduction, or significant upgrading, of baby bonuses in a number of countries such as Australia, Germany, Canada (the province of Québec), or Spain, it appears that benefits of this sort are among the most popular family policy measures explicitly aimed at increasing fertility. This series of policy changes also provides the opportunity to empirically evaluate the impact of these policies on fertility and other outcomes of interest, most notably mothers' and newborns' health. Because measuring the long-run effects of such benefits is inherently difficult, however, most of the available evidence is on the short-term effects of introducing, or announcing the introduction of, measures of this sort. Indeed, a number of recent studies evaluating these policy experiments has shown that the introduction of such policy measures is usually associated with considerable behavioral responses in the short-run, potentially resulting in negative health effects for the mother and/or her newborn child. ${ }^{1}$

In the case of Australia, the government publicly announced on May 11, 2004, that it would pay $3000 \$$ (about $2190 €$ ) to each family of a newborn child born on or after July $1,2004 .^{2}$ The introduction of the bonus was thus announced in advance of the effective policy change, creating an incentive to delay births. In their empirical evaluation of the policy change, Gans and Leigh (2009) find that $6 \%$ of the births (more than 1000 births) expected to happen in the 28 days preceding the actual policy change were moved to July 1st 2004 or later to become eligible for the baby bonus. They find that most of the effect is due to a corresponding timing of induction and cesarean section procedures. Consequently, they also find that children who were moved into the eligibility period were more likely to be of high birth weight. ${ }^{3}$ Drago et al. (2011) also analyze the introduction of the birth benefit in Australia, but use a different data source than Gans and Leigh (2009). They find that the birth benefit had both a positive effect on women's fertility intentions and one of modest size on the effective birthrate. Positive fertility effects

\footnotetext{
${ }^{1}$ Substantial effects on birth timing are also found by Dickert-Conlin and Chandra (1999) and Chen (2011) who study the effects of tax incentives on the timing of births in the U.S. and France, respectively. Other studies have found that taxes distort other types of individual behavior such as marriages (Alm and Whittington, 1995) or even deaths (Kopczuk and Slemrod, 2003).

${ }^{2}$ More precisely, the baby bonus replaced another policy previously in force. In the previous system, the bonus was dependent on the income of the primary caregiver in the year the child was born and was in the form of a refundable tax offset. Most, though not all, households had an incentive to move births to July 1, 2004, or later. See Gans and Leigh (2009) for details.

${ }^{3}$ This in turn may imply long-run effects of short-run behavioral responses, since birth weight is suspected to be causally related with later labor-market outcomes (e.g. Black et al., 2007).
} 
from the Australian policy change are also reported in Lain et al. (2009). Tamm (2009) analyzes a similar reform in the system of family benefits in Germany, the introduction of parental leave benefits ("Elterngeld") as of January 1, 2007. ${ }^{4}$ As in Australia, the announcement happened only a few weeks in advance, meaning that the policy change could only affect the timing, but not the number of births. Similarly to Gans and Leigh (2009), Tamm finds that a substantial number of births were delayed and moved into the eligibility period for the new benefit system. Specifically, he concludes that almost $8 \%$ of births (around 1000 births) that could have been expected in the last week of December were shifted to the first week of January 2007. He also finds a slight increase in birth weight among the births most likely to have been shifted (i.e. January versus December births). Further empirical evidence comes from the experience of a cash benefit for newborn children in place from May 1988 until September 1997 in the province of Québec, Canada. The transfer depended on the child's parity and paid up to $5840 \$$ (about $4260 €)$ per child. Both Duclos et al. (2001) and Milligan (2005) find sizeable increases in fertility following the introduction of the bonus in the province of Québec relative to the rest of Canada. For example, Milligan (2005) estimates that the birth subsidy increased fertility by as much as $25 \%$ (among families eligible for the full amount of the benefit). Moreover, both studies find evidence of heterogeneous fertility responses, but neither looks at health outcomes of either mother or child. Finally, a recent evaluation of the introduction of a universal child benefit in Spain also finds a sizeable increase in the number of conceptions shortly after the introduction of the benefit, but no effect on child mortality (the only health indicator for the child) or mother's self-assessed health (Gonzalez, 2011). ${ }^{5}$

In this paper we study the fertility effects, as well as the potential health consequences for both mother and newborn child, following the announcement of the abolition of the Austrian baby bonus as of January 1, 1997. The Austrian baby bonus amounted to a maximum of $1090 €$ per child in 1996, the year before the abolition, and was paid conditional on medical

\footnotetext{
${ }^{4}$ As in the case of Australia, the German policy changed incentives differently for households with different characteristics. Generally, households with women working before giving birth, those planning to work shortly following birth, or those with high income received higher benefits after the reform and thus had an incentive to delay their births. See Tamm (2009) for details.

${ }^{5}$ The Spanish government announced on July 3, 2007, that all mothers giving birth on July 1, 2007, or later would receive a universal child benefit of $2500 €$ (the benefit did not last long and has already been rescinded). Because the date of the introduction of the benefit was not made public in advance there was - unlike in Australia and Germany - no potential for (selective) delay of births. Nonetheless, since the timing of conception can be manipulated, there is still potential for differential responsiveness once the introduction of the benefit has been announced.
} 
examinations of both mother and newborn child. The unique feature of this policy change is that the elimination of the benefit was announced about ten months prior to enactment, creating the potential for an "abolition effect" because prospective parents had both an incentive and the opportunity to move their baby plans forward. Although the response window in order to qualify for the birth benefit before its abolition was only limited to three weeks, the early announcement could have increased the number of babies born in the month prior to the policy change. On top of this, pregnant women with a due date close to the date of the policy change might have manipulated the exact day of birth by means of a medical intervention (i.e. cesarean section). We also explore whether there are heterogeneous responses to the policy change. This issue is of particular interest because maternal characteristics are directly related to the probability of experiencing complications during delivery, implying that heterogeneous fertility effects may be mechanically associated with the likelihood of birth complications. Moreover, if differences in these maternal characteristics are directly related to baby's health, differential sensitivity may lead to differences in the health of newborn children.

Drawing on monthly data from the Austrian birth statistics, we find that about $8 \%$ (roughly 600) more babies were born in the month before the abolition, relative to the number of children that would have been expected in the absence of the policy change, as a consequence of the public announcement. We further present evidence suggesting that conception timing rather than birth timing is the source underlying the fertility effect. Considering the short response window of a maximum of three weeks, the estimated impact on fertility is actually quite large. We also find that the responsiveness to the policy change depends on maternal characteristics, implying that there is a compositional change in the characteristics of mothers who gave birth in the month before abolition compared to mothers usually giving birth in December. An additional analysis of birth procedures uncovers a significant increase in the incidence of labor complications of about one percentage point (corresponding to a relative increase of about $14 \%$ ). We also find that only $11-13 \%$ of this increase can be attributed to selective fertility responsiveness, while we interpret the remaining $87-89 \%$ as being caused by a corresponding increase in stress because of a mistiming of pregnancies (i.e. pregnancies that occurred earlier than initially planned or desired). Interestingly, however, and despite the additional risk to which both mother and child are exposed, we do not find any adverse health effects for the newborn child on the indicators that we are able to observe. 
The remainder of this paper is organized as follows. In section 2 we provide some background information on the baby bonus in Austria. This is followed by a short discussion of the data source and some descriptives in section 3. We present our estimates of the fertility response following the announcement of the abolition of the baby bonus in section 4 . We also present several robustness checks and examine whether there is heterogeneity in the fertility response with respect to various maternal characteristics. Section 5 examines whether mothers (un)consciously take increased health risks for themselves and/or their babies when rescheduling the timing of conception or birth. Section 6 concludes.

\section{The Austrian Baby Bonus}

\subsection{Institutional Background}

The Austrian baby bonus ("Geburtenbeihilfe") was first introduced on January 1, 1968, as an untaxed single payment per live birth. As table 1 shows, the bonus was subsequently expanded several times after its introduction. Specifically, the payment of the bonus was made conditional on medical examinations both during pregnancy and after childbirth in 1975 and, the payment of the bonus was consequently partitioned. After the last expansion of the birth benefit in January 1987, the maximum benefit possible amounted to $1090 €$ per child and was paid in five consecutive rates. The first rate of the bonus was paid immediately after birth, the second rate one week after birth, and the remaining three rates were paid after the child's first, second, and fourth birthday.

\section{Table 1}

Policy makers wanted to sustain the incentive for mothers to continue with medical examinations for themselves and their newborn children even after the abolition of the baby bonus; they thus introduced an alternative incentive, the so-called "Mutter-Kind-Pass", (which is in fact still in place today). It consists of a single bonus of $145 €$ per birth; the payment is conditional on both mother and child undergoing specific medical examinations, and it is paid on the child's first birthday. Furthermore, eligibility to the new bonus is confined to mothers who are the child's primary caregiver and to households whose income does not exceed a given 
threshold in the year of birth. ${ }^{6}$ Thus, depending on household income, the abolition of the birth benefit meant a cut in cash benefits amounting to either $945 €$ or $1090 €$ (equivalent to a cut in benefits of $87 \%$ or $100 \%$, respectively). For a full-time employee (not household) with median labor earnings in 1996 equal to $20,991 €$, the full amount of the baby bonus was worth approximately $4.5 \%$ of his or her annual earnings (equivalent to about 2.3 weeks' income).

Compared to other family benefits, the baby bonus was rather modest in size. Aside from the birth benefit, three basic other types of family benefits existed (and still exist today). The most important (i.e. substantial) benefit is the family benefit ("Familienbeihilfe"), which is paid until the child's 18th birthday at the minimum. In 1997 it amounted to $95-134 €$ per month, depending on the child's age. Parental leave benefits were paid over a period of 1.5 years at that time, and amounted to $340 €$ per month. However, until another major reform in 2002, these benefits were tied to the mother's employment before giving birth. Finally, there is a monthly tax allowance for children who live in the same household as the parent filing the tax report. The tax allowance amounted to $25-51 €$ per month in 1997 , depending on the child's parity. Taken together, the baby bonus accounted for roughly $9 \%$ of all benefits (excluding tax allowances) accruing within the first four years of a child's life. ${ }^{7}$

\subsection{The Abolishment of the Baby Bonus}

The structural deficit of the federal budget was the ultimate reason for the abolition of the baby bonus. Generous social benefits combined with a deterioration of the labor market caused the ratio of social expenditure to GDP to skyrocket in the early 1990s. In spite of a temporary strengthening of the economy in 1994, social expenditures still rose, resulting in an overall increase of 36.5\% between 1991 to 1996 (Bauernberger and Guger, 1998). To decelerate rising social spending, the governing coalition between the conservatives and the social democrats finally passed an encompassing austerity package ("Strukturanpassungsgesetz") on July 1, 1996. Savings in family policy should be achieved by reducing maternity leave duration by half a year (from 24 to 18 months) and by abolishing the baby bonus. In terms of our identification

\footnotetext{
${ }^{6}$ Specifically, the maximum household income in order to qualify for the "Mutter-Kind-Pass" bonus is defined as 11·HBGr, with HBGr ("Höchstbemessungsgrundlage") denoting the upper income threshold above which the maximum pension benefit accrues. The threshold varies over time and amounted to $2965 €$ in 1997 . Thus annual household income had to be lower than $32,616 €$ in 1997 to qualify for the "Mutter-Kind-Pass".

${ }^{7}$ Neglecting tax deductibles, $[1090 € /(4 \cdot 12 \cdot 94.5 €+1.5 \cdot 12 \cdot 338.6 €+1090 €)] \simeq 0.093$.
} 
strategy, it is important to stress that, except for the birth benefit, all reforms decided on within the framework of the austerity program came into effect on July 1, 1996 - half a year before the abolition of the baby bonus.

Our review of newspapers suggests that the abolition must have been known by February 2, 1996, when the coalition between the conservatives and the social democrats first announced their agreement on the austerity package. There was extensive press coverage, but there was also confusion about the exact date of abolition, and the media initially discussed July 1, 1996 as the effective date of elimination. By the first week of March, however, shortly before the coalition's agreement on the structural adjustment law was signed (March 11, 1996), it must have been evident that the birth benefit would be canceled for all children born on January 1 , 1997 or later.

\subsection{The Window of Opportunity}

From what we have said above, it follows that there was a time gap of nearly ten months between the definitive announcement and the effective date of the policy change. Because the abolition of the baby bonus implies an increase in the price of a further child, prospective parents had a financial incentive to move their baby plans forward. From the time of the announcement of the elimination of the birth benefit, the time window during which a baby would have to be conceived in order to still get the birth benefit was very short, however.

In fact, we can be quite precise regarding the length of this time window because the duration of gestation is recorded in the birth statistics (more details are given in section 3 below). In the time period considered (i.e. the period from July 1990 until December 2006), the length of a pregnancy shows an approximately normal distribution, with a mean duration of 276 days and a standard deviation of about 14 days. The abolition of the bonus was definitely announced on March 7, 1996. After a mean pregnancy duration of 276 days, birth would take place on the December 8 at the earliest. The potential response time for women with average pregnancy duration therefore lasts 23 days (i.e. December 31 - December 8) - a little bit more than three weeks. The corresponding 90\% confidence interval ranges from 266 days to 287 days, implying that approximately 90\% (10\%) of all conceptions from March 19 (April 9) can be expected to be born before January $1,1997.8$ These simple calculations make it clear that

\footnotetext{
${ }^{8}$ Note that it is possible that some couples already tried to conceive after February 2, 1996, even though
} 
the window of opportunity was short, and that prospective parents thus had to respond quite immediately if they wanted to still be eligible for the bonus after the abolition had been made public.

\section{Data and Descriptives}

\subsection{Data Sources}

Our main data source are individual birth records from the Austrian birth statistics ("Geburtenstatistik"), covering all births from 1971 until 2006. In addition to information on year and month of birth, the data also contains some information on parental characteristics (such as age, education, marital status, labor market status, religion, and nationality) and, beginning in 1984, some health measures for the newborn child (such as weight, length, and apgar score). Moreover, information regarding the implemented birth procedure is recorded in the data after 1995.

Additional information on the costs of different birth procedures is obtained from data from the statutory health insurance fund ("Gebietskrankenkasse") of Upper Austria. ${ }^{9}$ This data set provides detailed information on health care services paid for by the fund between 1998 and 2003. We use this information to calculate the extra costs of a specific instrumental vaginal birth procedure, such as vacuum extraction, compared to a natural vaginal delivery.

\subsection{Sample Period}

Our baseline sample period basically covers the period from July 1990 until December 2006. We start the sample period in July 1990 because another major family policy reform took effect on that specific date (the reform basically involved a massive extension of the duration of parental leave benefits). ${ }^{10}$ The sample period is considerably shorter, however, when we

there was confusion about the exact date of abolition until March 7, 1996. It is therefore still possible to find an increase in births before December 1996 (see section 4.3 below).

${ }^{9}$ Upper Austria ("Oberösterreich") is the third largest state (with respect to the number of residents), and is located in northeastern Austria (bordering both Germany and the Czech Republic).

${ }^{10}$ It is worth mentioning that our basic sample period covers, besides the austerity package and the abolition of the baby bonus, two other major policy changes in family law that were made public in August 2001. First, parental leave duration was extended from 18 to 30 months for all mothers who were on maternity leave during August 2001, gave birth after July 2000, and earned no more than $14,600 €$ per year. A second reform was enacted in January 2002 and decoupled eligibility to maternity leave benefits from any prior work requirement, thus extending eligibility to self-employed women and mothers not in the labor force. 
focus either on newborn's health or on birth procedure due to data availability.

As we will show below, however, the exact length of the sample period does not appear to have any substantial impact on our results. In fact, our estimates of the policy impact turn out to be robust across a wide range of alternative sample periods (as will be shown in section 4.2 below).

\subsection{The Monthly Birth Count, 1990-2006}

Figure 1 shows both the observed and the de-trended absolute number of monthly births from January 1990 to December 2006.

\section{Figure 1}

Panel (a) shows the absolute number of monthly births, with dots (triangles) indicating the number of births in December (January) in any given year. Two specific features stand out clearly. First, there is a strong non-linear trend in the number of births, with a pronounced hump shape in the 1990s (presumably reflecting the large immigrant influx from the Balkan countries at that time) and a flattening afterwards. The number of monthly births increased from about 7500 births per month in the early 1990s to a high of somewhat more than 8000 births per month in the mid 1990s. The number of births began to decrease again at the end of the 1990s, when the number of births seems to have stabilized at about 6500 births per month. The second outstanding feature is the existence of a pronounced cyclical pattern within any given year. Within each year, many more children are born in the middle rather than at the end of the year. ${ }^{11}$ Even more striking is the fact that, the number of children born in December over the whole period considered never exceeds the number of births in January - except in December 1996, the month just before the birth benefit was effectively abolished.

We remove the time trend from the data in panel (b) and thus make the monthly cyclicality in births more evident. In each year, the number of births is lowest at the end of the year and highest in the middle. The year 1996 clearly stands out regarding the number of children,

\footnotetext{
${ }^{11}$ There are basically two explanations for the seasonal pattern in birth timing. First, there are seasonal fluctuations in marriages which may lead to fluctuations in births. In fact, marriage seasonality in Austria matches the seasonal pattern in births if newlywed couples immediately stop using contraceptives with the intent of conceiving. A second explanation are parental preferences regarding the month of birth (Rodgers and Udry, 1988). See also Buckles and Hungerman (2008) for a detailed discussion of both causes and consequences of seasonality in births.
} 
especially those born in December. In fact, the de-trended number of births in December 1996 (463) corresponds to the 95th percentile of the distribution of de-trended number of births over the entire period and to the 1st percentile of the distribution of the de-trended number of births in December.

\section{The Fertility Response}

\subsection{Estimating the Fertility Response}

A couple of issues have to be considered when estimating the fertility response following the announcement of the abolition of the baby bonus. First note that we have to rely on the longitudinal patterns in the number of births to estimate the policy impact on the birth count. Because there is no control group available, the outcome in the absence of the policy change needs to be predicted using regularities in the data before and/or after the policy change. Another issue is that there may be a permanent effect from the abolition of the baby bonus on fertility behavior. This implies that we should be cautious when using, or potentially try to do without, data from after the baby bonus has been abolished (i.e. data after December 1996). Second, figure 1 suggests that we should try to model a flexible time trend in the number of births when using a longer sample period. However, it turns out that fitting a flexible time trend becomes somewhat difficult when only using data from before the policy change because observations at the boundary of the sample period have a strong impact on the estimated time trend in case of a nonlinear trend (and thus on the estimate of the fertility response as well). We use two distinct empirical strategies to cope with these issues in the following.

Our first empirical strategy only uses data from before the policy change until (and including) October 1996, but refrains from fitting a flexible time trend. ${ }^{12}$ At the same time, we want to focus on a time period within an approximately linear time trend in the number of births. A simple visual inspection of the observed number of births, as in figure 1, suggests that there is a linear time trend in the monthly number of births from about 1992 onwards. We thus

\footnotetext{
${ }^{12}$ November 1996 births are excluded as well because, according to the distribution of the pregnancy duration, about $5 \%$ of responding mothers who conceived immediately after announcement delivered before November 28,1996 . This follows from the $90 \%$ confidence interval that ranges from 266 to 287 days of pregnancy. More importantly, it turns out that the initial confusion about the exact date of the abolition was less pronounced than our reading of the newspapers suggested (see section 2.2 again) and that many prospective parents must have known the date of the abolition already before the first week of March. See section 4.3 below.
} 
regress the absolute (or, alternatively, the log) number of births on a linear time trend and a series of dummies for calendar month, denoted by $\gamma_{m}$, on a sample period of varying length

$$
b_{t}=\alpha+\beta t+\gamma_{m}+\varepsilon_{t}
$$

with $t \in\{T, T+1, \ldots,-4,-3\}$, denoting the number of months that have passed since January 1997. Thus $t$ is set equal to 0 in January 1997, and a one-unit change in $t$ thus represents one month. As already mentioned, the latest observation included is October 1996, where $t$ is equal to -3 . For our main results, we let $T$ be equal to either $-50,-38$, or -26 , such that the sample period consists of either 48, 36, or 24 months (in section 4.2, we show that our results are also robust to alternative sample periods).

In the second strategy, we use observations from both before and after the policy change, implicitly assuming that only those parents move birth forward who originally wanted to give birth in the time period that we omit from the sample period. Using observations from after the policy change as well makes it possible to use a much more flexible form for the time trend in the number of births

$$
b_{t}=\alpha+\beta \kappa(t)+\gamma_{m}+\delta 1(t \geq 0)+\varepsilon_{t},
$$

with $t \in\{-78,-77, \ldots,-2,-3, T, T+1, \ldots, 118,119\}$. That is, $t$ runs from July $1990(t=$ $-78)$ to December $2006(t=119)$ in this case, but we leave out a period of varying length in the middle of the sample period, denoted by $T$. We let $T$ equal to 0,12 or 24 and thus the period that is left out from the analysis to correspond to either 2, 14, or 26 months. In this second scenario we allow for a flexible time trend in the number of births, using a fourth-order polynomial in $t$, denoted by $\kappa(t)$. We also allow for the possibility of any permanent effect of the abolition of the bonus on the number of births by including a dummy variable that takes on the value of 1 if $t$ is equal to or greater than 0 . Thus $\delta$ will capture any permanent fertility effect of the abolition of the bonus. ${ }^{13}$

For either strategy, we then use the estimates from the above regressions in a second step to make an out-of-sample prediction of the number of babies that would have been born in

\footnotetext{
${ }^{13}$ Similarly, we also include additional dummies for the other major policy changes that were implemented during the sample period; see footnote 10 for details.
} 
December 1996 in the absence of the policy change, denoted by $\widehat{b}_{-1}$. The difference between the observed and the predicted number of births in December 1996,

$$
b_{-1}-\widehat{b}_{-1}
$$

is our estimate of the impact of the (public announcement of the) abolition of the baby bonus on the number of children born in December $1996(t=-1)$, relative to the number of children we would have expected in the absence of the policy change (or, alternatively, in the case that the abolition were not publicly announced in advance).

\section{Table 2}

Table 2 shows results for both the absolute number of births and the log number of births and for the two different strategies outlined above. ${ }^{14}$ Panel A shows the resulting estimates when using data from before the policy only, but for three different sample periods, combined with a simple linear time trend in each case. Depending on the length of the sample period, estimates of the additional number of births in December 1996 range from 487 to 592 births. In all three cases, the estimate of the extra births turns out to be statistically significant. In relative terms, the estimates imply that about $6.8 \%(=100 \% \cdot[487 /(7613-487)])$ to $8.4 \%$ $(=100 \% \cdot[592 /(7613-592)])$ additional children were born due to the announced abolition of the bonus. We get very similar estimates when using the log number of births as dependent variable, as shown in the lower part of panel A. Relative effects in this case range from about $6.8 \%(=100 \% \cdot[\exp (0.66)-1])$ to $8.1 \%(=100 \% \cdot[\exp (0.078)-1])$.

It turns out that our alternative strategy yields very similar estimates, as shown in panel B. Depending on the sample period, estimates range from a low of $664(9.5 \%)$ to a high of 698 (10.1\%) extra births in December 1996. Using data from after the policy change as well thus yields somewhat larger estimates than those we obtain when we only use data from before the policy change, but the point estimates based on the two strategies are in fact not statistically different from each other. Again, using the log number of births yields very similar quantitative implications.

\footnotetext{
${ }^{14}$ We also re-ran our baseline regressions using the total fertility rate as dependent variable. Results turn out to be qualitatively similar.
} 


\subsection{Robustness}

We first test the sensitivity of our baseline results with respect to (additional) variations in the sample period. Remember that when only using observations from before the abolition of the bonus, our baseline model uses either 24,36 , or 48 months prior to the policy change in order to predict the December 1996 birth count. Panel A of table 3 shows the resulting minimum and maximum estimate of the fertility response when we vary the length of the observation period, in steps of one month, from 24 to 48 months. Estimates turn out to be robust to this variation in the sample period. The resulting minimum (maximum) estimate equals 417 (622) births, an estimate well within the range of our baseline estimates. The same conclusion applies to the range of estimates when using the log number of births as dependent variable.

When using observations from both before and after the policy change, our baseline result basically relies on the whole observation period from July 1990 to December 1996, but excludes a period in between of varying length. Panel B of table 3 shows estimates when we hold the omitted period fix, but vary the length of the sample period before and after, from a minimum of 24 months to a maximum of 76 months (both before and after the omitted period). Again, estimates turn out to be surprisingly robust across the various sample periods. The minimum (maximum) estimate among all estimates is equal to 309 (684) additional births in December 1996. As above, we find a quantitatively similar pattern of estimates when modeling the log number of births instead of the absolute number of births.

Table 3

As an additional robustness check, we apply an alternative two-step procedure. In a first step, we de-trend the whole time series using a conventional Hodrick-Prescott filter. We then regress the de-trended number of births on a series of monthly dummies in the second step. ${ }^{15}$ As in the baseline model, we use the four foregoing years to predict the de-trended number of births in December 1996. Moreover, this exercise is not only done for the real policy change but also for hypothetical policy changes in December 1993, 1994 and 1995. Panel C of table 3 presents the results. The first column shows that the impact of the abolition is estimated to amount to 455 additional births. This estimate is slightly smaller than the estimate obtained

\footnotetext{
${ }^{15}$ Specifically, we run the following regression: $\ddot{b}_{t}=\alpha+\gamma_{m}+\varepsilon_{t}$, where $\ddot{b}_{t}$ denotes the de-trended number of monthly births and $\gamma_{m}$ denotes the inclusion of a full set of monthly dummies.
} 
by the baseline model, but it is well within the estimated range of estimates from panel A above (i.e. the estimates are not significantly different from each other). ${ }^{16}$ The results presented in the subsequent columns show estimates of the residual number of births in the hypothetical scenario that the policy change happened one, two or three years earlier than it actually did. It is immediately evident that none of the placebo regressions yields a residual that is statistically different from zero, underlining our argument that the announced abolition of the baby bonus increased fertility in the short-run.

\subsection{Additional Births in November 1996}

Even though there was initially quite some confusion in the press about the exact date of the abolition, it is still possible that we can already observe some extra births in November 1996 since, in principle, the true date of the abolition was already known by February 2, 1996 (the date when the austerity package was signed). With this in mind, we thus re-run our baseline regressions for births in November 1996.

Table 4

The resulting estimates are shown in table 4. Somewhat surprisingly we already find a substantial, and statistically significant, number of additional births in November 1996. Our corresponding estimates range from 279 to 442 extra births in November 1996 (about 60\% to $75 \%$ the size of the corresponding estimates for December 1996). Moreover, all estimates reach statistical significance at any conventional level. It thus appears that a significant number of mothers/parents must have known or must have correctly anticipated that the baby bonus would not be abolished before January 1997. This result implies that our main results based on births in December 1996 unambiguously represent a lower bound on the overall fertility effect.

\subsection{Conception (Re-)Scheduling vs. Timing of Births}

Thus far we have ignored the fact that we expect to see extra births in December 1996 for two very distinct reasons. First, as we have discussed above, there was a short window of

\footnotetext{
${ }^{16}$ It is actually quite intuitive that the estimate based on the de-trended number of births is smaller because the filter fits the time trend using all observations - including the extra births in December 1996. As a consequence, the time trend is biased upward around the date of the true policy change. This in turn results in a downward biased estimate for the fertility response in December 1996.
} 
opportunity of about three weeks during which prospective mothers could try to get pregnant in order to give birth before January 1, 1997 and still get the birth benefit. A second reason, however, may be that women with a due date close the date of abolition could have manipulated the exact day of birth by means of a surgical intervention (i.e. cesarean section). We now try to gain some insight into the effective source of the additional births that we observe in December 1996. To distinguish between the two channels, we now focus on the date of conception, which can easily be derived from the available information on the duration of pregnancy and the date of birth. Note that, because the abolition of the birth benefit was announced after the first week of March, the three week response window falls entirely into the month of March. Hence the comparison of the impact on the number of conceptions in March with the impact on the number of births in December 1996 is insightful in terms of whether conception (re-)scheduling or birth timing is the primary cause of the extra births in December 1996. Analogous to the baseline model, we use data from the preceding 48 months to make a simple prediction of the number of babies that would have been conceived in March 1996 in the absence of the policy change.

\section{Table 5}

The resulting estimates, shown in table 5 , imply that 631 , or about $9.1 \%(=100 \%$. 631/(7547-631)), additional children were conceived in March 1996 on top of what would have been expected in the absence of the policy change. Remember that our baseline model yields an estimate of 591 additional births in December 1996 (see table 2) - almost the same number as our estimate for the additional number of conceptions in March 1996. The fact that both results are very much in line with each other suggests that conception (re-)scheduling, rather than birth timing by medical intervention, is the underlying cause of the observed fertility response. ${ }^{17}$ Finally, note that it is likely that the number of couples trying to move baby plans forward is likely to be higher than those 616 who finally succeeded. ${ }^{18}$

\footnotetext{
${ }^{17}$ Section 5.1 below provides additional evidence in line with this result, showing that there is no impact on the fraction of cesarean sections conducted in December 1996.

${ }^{18} \mathrm{~A}$ rough approximation of the total number of responding couples is obtained by multiplying the number of extra births with the probability of becoming pregnant within three weeks. Gnoth et al. (2003) study the likelihood of spontaneous conception in subsequent cycles for a random sample of German women and find that cumulative probabilities of conception at one, three, six and twelve cycle(s) are, respectively, 38\%, $68 \%$, $81 \%$ and $92 \%$. A linear interpolation between month zero and month one yields a cumulative probability of conception of $29 \%$ at week three, which implies that approximately $2038(=591 / 0.29)$ couples were induced to
} 


\subsection{Heterogeneous Responses}

We next study whether the fertility responsiveness depends on maternal characteristics. For this purpose we simply repeat our baseline regression for subgroups of mothers based on characteristics such as birth parity, age at birth, education, labor market status one year before giving birth, nationality, and marital status. We would expect to see differences in fertility responsiveness for basically two reasons. First, couples with a lower socio-economic background might be more likely to respond than couples with a higher socio-economic background because their incentive is higher in relative terms. Second, differential awareness of the policy change is likely to also play an important rule. Such an analysis is interesting, as heterogeneous fertility responses may have direct implications for analyzing the health consequences of the policy change (see section 5 below).

\section{Table 6}

Table 6 presents the estimates from these various regressions and shows how the fertility effect can be attributed to different values of a given (maternal) characteristic. However, these shares are really only informative if we can compare them to the corresponding shares that would have occurred in the absence of the policy change. These figures are unobserved, but it turns out that average characteristics of mothers who gave birth in a particular calendar month are very stable over time. We thus simply compare mothers who give birth in December 1996 to mothers who give birth in December in other years (i.e. in the years when no policy change took place). The difference between these two figures, in percentage points, is shown in the right-hand part of table 6 .

First, regarding birth parity, our results suggest that the share of mothers who gave birth to their first child is almost 6 percentage points higher among responding mothers than among mothers usually giving birth in December. The overall fertility response thus appears to be driven by mothers who had their first rather than a higher order child. Our results also show that responsive mothers are either younger than 20 or aged between 30 and 34 . In contrast to our prior expectations, the responsiveness of women with the lowest educational background is disproportionally small. As already mentioned, however, this may (plausibly) reflect the 
fact that women with different socio-economic backgrounds differ in their media-usage and therefore in their awareness of the policy change. Specifically, varying awareness of the policy change may explain why women with low education and/or foreign-born women are less likely to respond to the abolition of the baby bonus. At the same time, the responsiveness of mothers with an intermediate technical and vocational school turns out to be exceptionally large, while the observed share of women holding a college or university degree more or less coincides with the expected share. In line with expectations, however, is the much higher responsiveness of women who were not employed compared to previously employed women. The share of mothers who were not employed is 17 percentage points higher than it would have been in the absence of the announced abolition of the bonus. Finally, responding mothers are also less likely to be married. Overall, there is substantial heterogeneity in the fertility response which we have to take account of when we focus on the impact on mothers' and newborns' health.

\section{$5 \quad$ Taking Risks for the Bonus?}

\subsection{Birth Complications}

We now try to understand whether mothers (un)consciously take health risks for themselves and/or their newborn child when trying to obtain the bonus. We start looking at birth complications. In the following we consider instrumental vaginal delivery mechanisms (forceps delivery, vacuum extraction, and breech delivery) as indication of birth complications, as all three delivery methods involve potential health risks for mother and/or child and are thus applied in emergency situations only. While the former two types of assisted deliveries are used in case of maternal exhaustion, fetal distress, or a combination of both, the latter method is used in labor with a baby in head-down position. For simplicity, we will refer to these instrumental vaginal delivery mechanisms as "birth complications" in what follows. Cesarean section is considered separately because it has been performed upon request more recently for deliveries that could otherwise have been natural, even though it is usually performed only when a vaginal delivery would put baby's or mother's life or health at risk. Accordingly, we think that a cesarean section must be viewed as an instrument for deliberate birth timing - in line with the results from Gans and Leigh (2009) and Tamm (2009).

Two important issues have to be considered in this context. First, we have previously 
shown that responsive mothers are a selected group of mothers. If the characteristics of these mothers are associated with preexisting conditions encouraging birth complications, differential fertility responsiveness may mechanically affect the incidence of specific birth procedures. ${ }^{19}$ At the same time, couples who were induced to conceive a baby earlier than actually intended might be faced with additional stress, and this additional stress may in turn increase the risk for birth complications as well. ${ }^{20}$ In fact, we may plausibly think of these babies moved forward as mistimed pregnancies, in the sense that these pregnancies occurred earlier than initially planned or desired, and there is evidence that mistimed pregnancy is associated with additional stress and a increased risk of birth complications. ${ }^{21}$ In the end, we are mainly interested in knowing whether any increase in birth complications remains once we net out compositional changes in observable characteristics.

To estimate the impact of the abolition on the incident of birth complications, we use basically the same regression specification as above but with the percentage share of birth complications as dependent variable. Because information on birth procedure is only reported from 1995 onwards, we use data from both before and after the policy change to estimate the impact on birth procedures. Specifically, the sample period covers the period from January 1995 to October 1996 and from January 1998 to December $2006 .^{22}$

Table 7

Table 7 reports the baseline result for the percentage of overall birth complications (column 2), as well as for single birth procedures (columns 3 to 5). Finally, the last column shows the

\footnotetext{
${ }^{19}$ Rayl et al. (1996) show that maternal characteristics like primiparity and older maternal age are associated with an increased risk of breech birth. The Austrian data show a very similar picture: the major determinants for both instrumental non-vaginal and instrumental vaginal delivery are primiparity and older age (detailed results are given in appendix table B.1). Since both of these characteristics are also associated with higher responsiveness to the abolition of the benefit, selection is expected to increase the incidence of birth complications among mothers who delivered in December 1996.

${ }^{20}$ Because of the short response window, reacting to the announced policy change necessitates immediate action, while living conditions may not yet be geared to the needs of a (further) offspring. For example, the housing situation might be unsuitable in terms of space or child care possibilities, perhaps the current job situation offers no chance for part-time work, or health-related behavior like smoking or nutrition ought to be changed.

${ }^{21}$ Mohllajee et al. (2007) find that women who had a mistimed compared to an intended pregnancy are more likely to smoke during pregnancy, report higher stress values, and have more complicated births. Moreover, Leathers and Kelley (2000) find unintended and mistimed pregnancies among first-time mothers to be associated with an increase in the risk of postpartum depression symptoms. See Pulley et al. (2002) for a detailed discussion of the extent of pregnancy mistiming and its association with maternal characteristics and behaviors.

${ }^{22}$ Appendix table B.2 shows results from running the same model, but excluding either two or three years (instead of one year) in between.
} 
estimated impact on the percentage of cesarean sections. We find that there is a statistically significant and substantial increase in the percentage of overall birth complications of about 0.9 percentage points in the month prior to abolition of the baby bonus. Note that this corresponds to a relative increase in the probability of experiencing some birth complication by almost $14 \%(=100 \% \cdot(0.924 / 6.778))$. In absolute numbers, the figures imply that 70 additional complications were observed in December 1996. The following three columns show results by individual delivery method. Estimates show a significant increase for all but one of the instrumental vaginal birth procedures (forceps delivery). The overall increase in the share of labor complications is thus mainly driven by an increase of breech deliveries and vacuum extractions. In terms of non-vaginal instrumental delivery methods, column 6 reveals an insignificant estimate for the percentage share of cesarean sections, suggesting that women did not use this method to deliberately manipulate the date of birth.

Finally, a simple decomposition exercise based on our regression estimates (see appendix A for details) shows that only a minor fraction of the observed increase in the likelihood of a birth complication is explained by compositional effects due to differential responsiveness to the policy change. Specifically, the decomposition results reveal that only about $11-13 \%$ of the differential are explained by differences in observed maternal characteristics. Accordingly, the remaining $87-89 \%$ of the observed increase in birth complications must be due to other, unobserved factors. As we have discussed above, additional stress due to the mistiming of a pregnancy is likely to play a key role here, even though we cannot rule out that other, unobserved maternal characteristics (such as mothers' health status) explain some of the increased risk of experiencing some birth complication as well.

\subsection{Newborns' Health}

We next explore the direct impact on newborns' health using several distinct health measures: the incidence of a preterm birth, low birth weight, length at birth and the apgar score, which is a measure for quickly assessing the health of a newborn. ${ }^{23}$ We expect to find differences in the health of children born in December 1996 for the same reasons as for birth complications.

\footnotetext{
${ }^{23}$ The apgar score is used to assess the health of a newborn immediately after birth. In our data, the apgar score one, five, and ten minutes after birth is recorded. The apgar score assesses five different categories (heart rate, breathing, muscle tone, reflex response, and skin color) with a score between zero and two each, where the scores are simply added up. Low values on the score are indicative of poor health. In the regression reported below, we use the average of a child's score 1, 5, and 10 minutes after birth.
} 
If newborns' health is associated with characteristics of the mother, differences in the health of newborn children may simply result from heterogeneous fertility responses. While compositional changes may have positive or negative effects on newborns' health, the additional stress triggered by a mistimed pregnancy is expected to unambiguously harm the health of the newborn. ${ }^{24}$

\section{Table 8}

Table 8 shows the resulting estimates for four different, more or less direct, health measures. All estimates are derived applying the same estimation strategy as in the case of the fertility responsiveness (see section 4 above). The sample period covers the four years prior to the abolition of the benefit. The first column shows the effect on the percentage of newborn children with a low apgar score (i.e. a score lower than 7). The resulting point estimate is small and statistically not different from zero. Similarly, we do not find any negative effect on the likelihood of small birth length, of low birth weight or of a premature birth. ${ }^{25}$ Overall, we thus find no statistical evidence for any (immediate) negative impact on the health of newborn children - despite the fact that we find evidence of increased labor complications, which would suggest that the abolition of the baby bonus put some children at risk.

\subsection{Additional Health Costs}

We can finally use the above results to roughly approximate the additional health costs arising from the relative increase in labor complications. To this end, we draw on additional data from the statutory health insurance fund of Upper Austria for the period from 1998 to 2003. We find that instrumental vaginal birth procedures are associated with substantially higher costs than spontaneous deliveries. Specifically, while a spontaneous delivery is associated with average costs of $1047 €$, an instrumental vaginal delivery (vacuum extraction, forceps, and breech delivery) is associated with average costs of $1494 €$. The costs of an instrumental

\footnotetext{
${ }^{24}$ This hypothesis is supported by Pulley et al. (2002) who find that the mistiming of a pregnancy positively correlates with the probability of a preterm delivery (and low birth weight). They conclude that pregnancies that are mistimed by more than a few months may have severe health consequences for both mother and child. See also table B.3 in the appendix.

${ }^{25}$ Note that it may make sense to look at the share of premature births conceived in March rather than born in December 1996. This is because babies conceived within the relevant time window of three weeks following the announcement, when born prematurely, would have been born at most 8.5 months later and thus probably already in November. However, this yields an insignificant estimate as well.
} 
delivery therefore exceed those of a spontaneous delivery by about $43 \%(=100 \% \cdot(1494 €$ $-1047 €) / 1047 €){ }^{26}$

To roughly approximate the additional health costs from the increase in birth complications, we only consider the extra complications that are likely due to stress resulting from the mistiming of births. If we further assume that observed maternal characteristics describe group differences comprehensively, this share is estimated to amount to about $87 \%$ (see appendix A). In absolute numbers, there are $61(\simeq 0.87 \cdot 70)$ additional complications in December 1996 that are due to unobserved factors. Multiplying the number of additional birth complications with the extra costs of hard childbirth yields an estimate of additional health costs of roughly $27,206 €(=57 \cdot 446 €)$. Compared to the costs which would have been incurred for these children in the absence of the policy change, i.e. if the fraction of birth complications had not increased, overall health costs are higher by a mere $0.38 \%$ $(\simeq[1047 \cdot(1-.07702)+1494 \cdot .07702] /[1047 \cdot(1-.06778)+1494 \cdot .06778])$. On the other hand, however, note that these costs do not yet cover any potential long-term consequences arising from complications during delivery.

\section{Conclusions}

We study the fertility and health effects preceding the abolition of the Austrian baby bonus on January 1, 1997. Even though the bonus was rather small relative to other family benefits available, it was still worth about $4.5 \%$ of the median annual labor income in the year of its abolition. Moreover, because the abolition was made public about ten months in advance, prospective parents not only had a financial incentive but also the possibility to react without the need of medical intervention.

We find that about $8 \%$ (roughly 600) more babies were born than in the absence of (the public announcement of) the policy change in December 1996, the month before the abolition of the baby bonus. This effect proves to be robust to a variety of robustness checks. Also,

\footnotetext{
${ }^{26}$ The additional costs of instrumental deliveries are attributable to extra staff inputs needed during delivery as well as to an extended stay in hospital. Our data reveal that women with an instrumental delivery stayed 3.7 days longer than women with a spontaneous delivery, a difference that is statistically significant at the one percent level. Petrou and Glazener (2002) find larger cost differences for Scotland for the years 1990/91. They estimate that the total health care costs of a spontaneous delivery amount to $1194 €$ and to $2249 €$ for an instrumental vaginal delivery. A meta-study by Henderson et al. (2001) finds that costs for a spontaneous delivery vary from $365 €$ to $625 €$, and costs for an instrumental delivery between $647 €$ and $995 €$.
} 
considering the fact that the window of opportunity was quite a short period of about three weeks only, the fertility response appears to be quite large. We also find (re-)scheduling of conceptions rather than direct birth timing (through medical intervention) to be the source of the fertility response. Additional results show that the fertility responsiveness depends on maternal characteristics such as birth order and age. One important consequence of such heterogeneity in the fertility response is a compositional change in the characteristics of December 1996 mothers (relative to mothers giving birth in December in any other year). Our analysis of birth procedures further reveals a significant and substantial increase in the fraction of mothers experiencing some kind of birth complications by about one percentage point (a relative increase in the likelihood of about $14 \%$ ). We calculate that only about $11-13 \%$ of this increase in birth complications can be attributed to changes in observable maternal characteristics. The remaining $87-89 \%$ of the increase in birth complications may be interpreted as being caused by an increase in stress due to the mistiming of pregnancies. However, the increase in birth complications notwithstanding, we do not find any adverse (immediate) impact on newborns' health. Finally, a rough approximation of the additional health costs incurred by the increase in labor complications suggests that about $27,000 €$ could have been saved if the announcement had been made three weeks later (or not at all).

There are two important implications that one may derive from our analysis. First, our results suggest that if the announcement of a policy change is such that it offers individuals the potential to react, it is likely to trigger substantial behavioral distortions in the shortrun. Hence, policy makers should be aware that not only a policy itself but also the public announcement of its abolition (or introduction) may have an impact on individual decisions. Second, and in contrast to what has been found by Gans and Leigh (2009) and Tamm (2009), we find no evidence for mothers having deliberately manipulated the date of birth by means of medical intervention (i.e. cesarean section). This suggests that there are significant differences in the willingness and/or feasibility to use medical intervention to exactly time the day of birth across different countries. 


\section{References}

Alm, J. and Whittington, L. (1995). Does the income tax affect marital decisions? National Tax Journal, 48, 565-572.

Bauernberger, J. and Guger, A. (1998). Slight Decline of the Social Expenditure/GDP Ratio. Austria's Social Expenditure in 1996. Austrian Economic Quarterly, 3(3), 147-152.

Black, S., Devereux, P., and Salvanes, K. (2007). From the cradle to the labor market? The effect of birth weight on adult outcomes. Quarterly Journal of Economics, 122(1), 409-439.

Blinder, A. (1973). Wage discrimination: reduced form and structural estimates. Journal of Human Resources, 8(4), 436-455.

Buckles, K. and Hungerman, D. (2008). Season of Birth and Later Outcomes: Old Questions, New Answers. NBER Working Papers No. 14573.

Chen, D. (2011). Can countries reverse fertility decline? evidence from france's marriage and baby bonuses, 1929-1981. International Tax and Public Finance, 18(3), 253-272.

Dickert-Conlin, S. and Chandra, A. (1999). Taxes and the Timing of Births. Journal of Political Economy, 107(1), 161-177.

Drago, R., Sawyer, K., Shreffler, K., Warren, D., and Wooden, M. (2011). Did Australia's Baby Bonus Increase Fertility Intentions and Births? Population Research and Policy Review, 30(3), 381-397.

Duclos, E., Lefebvre, P., and Merrigan, P. (2001). A natural experiment on the economics of storks: Evidence on the impact of differential family policy on fertility rates in canada. Cahiers de recherche CREFE/CREFE Working Paper No. 136.

Gans, J. and Leigh, A. (2009). Born on the first of July: An (un) natural experiment in birth timing. Journal of Public Economics, 93(1-2), 246-263.

Gnoth, C., Godehardt, D., Godehardt, E., Frank-Herrmann, P., and Freundl, G. (2003). Time to pregnancy: results of the german prospective study and impact on the management of infertility. Human Reproduction, 18(9), 1959-1966.

Gonzalez, L. (2011). The Effects of a Universial Child Benefit. IZA Discussion Paper No. 5994.

Henderson, J., McCandlish, R., Kumiega, L., and Petrou, S. (2001). Systematic review of economic aspects of alternative modes of delivery. BJOG: An International Journal of Obstetrics \& Gynaecology, 108(2), 149-157.

Kopczuk, W. and Slemrod, J. (2003). Dying to save taxes: Evidence from estate-tax returns on the death elasticity. Review of Economics and Statistics, 85(2), 256-265.

Lain, S., Ford, J., Raynes-Greenow, C., Hadfield, R., Simpson, J., Morris, J., and Roberts, C. (2009). The impact of the Baby Bonus payment in New South Wales: who is having "one for the country"? Medical Journal of Australia, 190(5), 238-241.

Leathers, S. and Kelley, M. (2000). Unintended pregnancy and depressive symptoms among first-time mothers and fathers. American Journal of Orthopsychiatry, 70(4), 523-531.

Milligan, K. (2005). Subsidizing the stork: New evidence on tax incentives and fertility. Review of Economics and Statistics, 87(3), 539-555. 
Mohllajee, A., Curtis, K., Morrow, B., and Marchbanks, P. (2007). Pregnancy intention and its relationship to birth and maternal outcomes. Obstetrics \& G Gynecology, 109(3), 678-686.

Oaxaca, R. (1973). Male-female wage differentials in urban labor markets. International Economic Review, 14(3), 693-709.

Petrou, S. and Glazener, C. (2002). The economic costs of alternative modes of delivery during the first two months postpartum: results from a scottish observational study. BJOG: An International Journal of Obstetrics \& Gynaecology, 109(2), 214-217.

Pulley, L., Klerman, L., Tang, H., and Baker, B. (2002). The extent of pregnancy mistiming and its association with maternal characteristics and behaviors and pregnancy outcomes. Perspectives on Sexual and Reproductive Health, 34(4), 206-211.

Rayl, J., Gibson, P., and Hickok, D. (1996). A population-based case-control study of risk factors for breech presentation. American journal of obstetrics and gynecology, 174(1), 2832 .

Rodgers, J. and Udry, J. (1988). The season-of-birth paradox. Biodemography and Social Biology, 35(3), 171-185.

Tamm, M. (2009). The Impact of a Large Parental Leave Benefit Reform on the Timing of Birth around the Day of Implementation. Ruhr Economic Papers No. 98. 
Table 1: The Austrian Baby Bonus

\begin{tabular}{|c|c|c|c|c|c|}
\hline \multirow[t]{2}{*}{ Date of implementation } & \multicolumn{5}{|c|}{ Time of payment: } \\
\hline & At birth & After 1st week & After 1st year & After 2nd year & After 4 th year \\
\hline January 1, 1968 & $123.5 €$ & & & & \\
\hline January 1, 1971 & $145.3 €$ & & & & \\
\hline January 1, 1975 & & $581.4 €^{1}$ & $581.4 €^{2}$ & & \\
\hline January 1, 1976 & $145.3 €^{1}$ & $436.0 €^{1}$ & $581.4 €^{2}$ & & \\
\hline January 1, 1982 & $145.3 €^{1}$ & $436.0 €^{1}$ & $581.4 €^{2}$ & $218.0 €^{2}$ & \\
\hline January 1, 1984 & $145.3 €^{1}$ & $218.0 €^{1}$ & $363.4 €^{2}$ & $218.0 €^{2}$ & \\
\hline January 1, 1987 & $145.3 €^{1}$ & $218.0 €^{1}$ & $363.4 €^{2}$ & $218.0 €^{2}$ & $145.3 €^{2}$ \\
\hline January 1, 1997 & \multicolumn{5}{|c|}{ Abolishment of the baby bonus } \\
\hline January 1, 1997 & "Mutter-I & ind-Pass" bonus & $145.4 €^{3}$ & & \\
\hline
\end{tabular}

Notes: ${ }^{1}$ Payment is tied to medical examinations of mother's during pregnancy and after birth. ${ }^{2}$ Payment is only made if child underwent certain medical examinations. ${ }^{3}$ The "Mutter-Kind-Pass" bonus still exists and is, as was the birth benefit, paid conditional on certain medical examinations of both mother and child. In contrary to the baby bonus, eligibility further requires the mother to be the primary caretaker and the yearly household income not to exceed 32'616€ during the year of birth. 
Table 2: Fertility Responsiveness

Panel A: Observations from before the abolishment only, linear time trend

Sample period

1994.11-1996.10 1993.11-1996.10 1992.11-1996.10

Number of births

Residual December 1996

Number of births December 1996

Number of observations

Adjusted R-Squared

p-value (F-statistic)

\begin{tabular}{ccc}
$486.625^{\star \star \star}$ & $562.583^{\star \star \star}$ & $591.333^{\star \star \star}$ \\
$(46.648)$ & $(109.883)$ & $(114.649)$ \\
7613 & 7613 & 7613 \\
24 & 36 & 48 \\
0.739 & 0.718 & 0.838 \\
0.000 & 0.000 & 0.000 \\
\hline & & \\
$0.066^{\star \star \star}$ & $0.075^{\star \star \star}$ & $0.078^{\star \star \star}$ \\
$(0.006)$ & $(0.014)$ & $(0.014)$ \\
8.938 & 8.937 & 8.938 \\
24 & 36 & 48 \\
0.732 & 0.715 & 0.839 \\
0.000 & 0.000 & 0.000 \\
\hline
\end{tabular}

Log number of births

Residual December 1996

Number of log births December 1996

Number of observations

Adjusted R-Squared

0.000

0.000

0.000

Panel B: Observations from before and after the abolishment, nonlinear time trend

Sample period

Number of births

Residual December 1996

Number of births December 1996

Number of observations

Adjusted R-Squared

p-value (F-statistic)

Log number of births

Residual December 1996

Number of log births December 1996

Number of observations

Adjusted R-Squared

p-value (F-statistic)

$\begin{array}{ccc}1990.7-1996.10 & 1990.7-1996.10 & 1990.7-1996.10 \\ \& 1997.1-2006.12 & \& 1998.1-2006.12 & \& 1999.1-2006.12\end{array}$

\begin{tabular}{ccc}
\hline $698.290^{\star \star \star}$ & $678.489^{\star \star \star}$ & $663.846^{\star \star \star}$ \\
$(129.264)$ & $(124.48)$ & $(123.07)$ \\
7613 & 7613 & 7613 \\
196 & 184 & 172 \\
0.956 & 0.960 & 0.962 \\
0.000 & 0.000 & 0.000 \\
\hline & & \\
$0.097^{\star \star \star}$ & $0.094^{\star \star \star}$ & $0.091^{\star \star \star}$ \\
$(0.018)$ & $(0.018)$ & $(0.017)$ \\
8.938 & 8.937 & 8.938 \\
196 & 184 & 172 \\
0.952 & 0.957 & 0.960 \\
0.000 & 0.000 & 0.000 \\
\hline
\end{tabular}

Notes: ${ }^{\star},{ }^{\star \star}$, and ${ }^{\star \star \star}$ denote statistical significance at the $10 \%, 5 \%$, and $1 \%$ level, respectively. In Panel $\mathrm{A}$, the time trend is assumed to be linear and the underlying sample period varies between two (column 2) and four (column 4) years prior to the effective policy change. In Panel B, the time trend is assumed to follow a fourth-order polynomial in calendar time, and a dummy variable for each major policy change within this period is included (1997.1, 2000.7, 2002.1). The underlying sample period basically covers observations from 1990.7 to 2006.12 , but leaves out a period in between which is potentially affected by the policy change. The period left-out varies between two months (i.e. November and December 1996) and three years and two months (i.e. the period from November 1996 to December 1998). 
Table 3: Robustness

\begin{tabular}{|c|c|c|c|c|}
\hline \multirow[t]{2}{*}{ Dependent variable } & \multicolumn{2}{|c|}{ Number of births } & \multicolumn{2}{|c|}{$\log$ (Number of births) } \\
\hline & Min & Max & Min & Max \\
\hline \multicolumn{5}{|c|}{ Panel A: Observations from before the abolishment only, linear time trend } \\
\hline Residual December 1996 & $\begin{array}{l}416.800^{\star \star \star} \\
(65.384)\end{array}$ & $\begin{array}{l}622.250^{\star \star \star} \\
(114.179)\end{array}$ & $\begin{array}{l}0.056^{\star \star \star} \\
(0.008)\end{array}$ & $\begin{array}{l}0.082^{\star \star \star} \\
(0.015)\end{array}$ \\
\hline Number of (log) births December 1996 & 7613 & 7613 & 8.937 & 8.937 \\
\hline Number of observations & 25 & 40 & 25 & 40 \\
\hline Adjusted R-Squared & 0.667 & 0.814 & 0.661 & 0.812 \\
\hline p-value (F-statistic) & 0.000 & 0.000 & 0.000 & 0.000 \\
\hline \multicolumn{5}{|c|}{ Panel B: Observations from both before and after the abolishment, nonlinear time trend } \\
\hline Residual December 1996 & $\begin{array}{l}308.955^{\text {}} \\
(102.14)\end{array}$ & $\begin{array}{l}683.588^{\star \star \star} \\
(140.048)\end{array}$ & $\begin{array}{l}0.041^{\star \star \star} \\
(0.015)\end{array}$ & $\begin{array}{l}0.095^{\star \star \star} \\
(0.019)\end{array}$ \\
\hline Number of $(\log )$ births December 1996 & 7613 & 7613 & 8.937 & 8.937 \\
\hline Number of observations & 61 & 81 & 61 & 65 \\
\hline Adjusted R-Squared & 0.941 & 0.909 & 0.937 & 0.863 \\
\hline p-value (F-statistic) & 0.000 & 0.000 & 0.000 & 0.000 \\
\hline
\end{tabular}

Panel C: Placebo regressions, de-trended number of births

\begin{tabular}{lccccc} 
& True policy change & \multicolumn{3}{c}{ Placebo regressions } \\
& $Y: 1996$ & & $Y: 1995$ & $Y: 1994$ & $Y: 1993$ \\
\cline { 2 - 5 } \cline { 5 - 6 } Residual December Year $Y$ & $455.025^{\star \star \star}$ & -182.784 & 72.090 & 68.241 \\
& $(143.074)$ & & $(150.167)$ & $(135.771)$ & $(145.206)$ \\
Number of births December $Y$ & 7613 & & 7232 & 7605 & 7672 \\
Number of observations & 48 & & 48 & 48 & 48 \\
Adjusted R-Squared & 0.648 & & 0.669 & 0.732 & 0.741 \\
p-value (F-statistic) & 0.000 & & 0.000 & 0.000 & 0.000 \\
\hline
\end{tabular}

Note: ${ }^{\star},{ }^{\star \star}$, and ${ }^{\star \star \star}$ denote statistical significance at the $10 \%, 5 \%$, and $1 \%$ level, respectively. Panel A uses a linear time trend with a sample period that varies between two and four years prior to the policy change. The model in panel B assumes a time trend that follows the fourth polynomial. The sample period varies between two and 6.25 (1990.7) years before and after the policy change. Panel C shows results from several placebo regressions based on the de-trended series of monthly births. See main text for details. 
Table 4: Extra Births in November 1996

Panel A: Observations from before the abolishment only, linear time trend

Sample period

Number of births

Residual November 1996

Number of births November 1996

Number of observations

Adjusted R-Squared

p-value (F-statistic)

Log Number of births

Residual November 1996

Number of births November 1996

Number of observations

Adjusted R-Squared

p-value (F-statistic)
1994.11-1996.10 1993.11-1996.10 1992.11-1996.10

\begin{tabular}{ccc}
$278.625^{\star \star \star}$ & $375.917^{\star \star \star}$ & $441.583^{\star \star \star}$ \\
$(46.649)$ & $(109.884)$ & $(114.649)$ \\
7125 & 7125 & 7125 \\
24 & 36 & 48 \\
0.740 & 0.718 & 0.839 \\
0.002 & 0.000 & 0.000 \\
\hline & & \\
$0.038^{\star \star \star}$ & $0.050^{\star \star \star}$ & $0.057^{\star \star \star}$ \\
$(0.006)$ & $(0.015)$ & $(0.015)$ \\
8.871 & 8.871 & 8.871 \\
24 & 36 & 48 \\
0.733 & 0.716 & 0.839 \\
0.002 & 0.000 & 0.000 \\
\hline
\end{tabular}

Panel B: Observations from both before and after the abolishment, nonlinear time trend

Sample period

Number of births

Residual November 1996

Number of births December 1996

Number of observations

Adjusted R-Squared

p-value (F-statistic)

Log number of births

Residual November 1996

Number of log births December 1996

Number of observations

Adjusted R-Squared

p-value (F-statistic)
$1990.7-1996.10 \quad 1990.7-1996.10 \quad 1990.7-1996.10$ \&1997.1-2006.12 \&1998.1-2006.12＆1999.1-2006.12

\begin{tabular}{ccc}
$409.418^{\star \star \star}$ & $377.032^{\star \star \star}$ & $392.720^{\star \star \star}$ \\
$(129.497)$ & $(124.795)$ & $(123.475)$ \\
7125 & 7125 & 7125 \\
196 & 184 & 172 \\
0.956 & 0.960 & 0.962 \\
0.000 & 0.000 & 0.000 \\
\hline & & \\
$0.061^{\star \star \star}$ & $0.056^{\star \star \star}$ & $0.057^{\star \star \star}$ \\
$(0.019)$ & $(0.018)$ & $(0.018)$ \\
8.871 & 8.871 & 8.871 \\
196 & 184 & 172 \\
0.952 & 0.957 & 0.960 \\
0.000 & 0.000 & 0.000 \\
\hline
\end{tabular}

Notes: ${ }^{\star},{ }^{\star \star}$, and ${ }^{\star \star \star}$ denote statistical significance at the $10 \%, 5 \%$, and $1 \%$ level, respectively. See notes of table 2 for additional details. 
Table 5: Conception (Re-)Scheduling vs. Birth Timing

\begin{tabular}{lcc}
\hline Dependent variable & Number of conceptions & Log number of conceptions \\
\cline { 2 - 3 } Residual March 1996 & $631.041^{\star \star \star}$ & $0.083^{\star \star \star}$ \\
& $(135.143)$ & $(0.017)$ \\
Number of (log) conceptions March 1996 & 7547 & 8.928 \\
Number of observations & 48 & 48 \\
Adjusted R-Squared & 0.783 & 0.784 \\
p-value (F-statistic) & 0.000 & 0.000 \\
\hline
\end{tabular}

Note: ${ }^{\star},{ }^{\star \star}$, and ${ }^{\star \star \star}$ denote statistical significance at the $10 \%, 5 \%$, and $1 \%$ level, respectively. The dependent variable is the number of conceptions in March 1996. The regression specification assumes a linear time trend. The sample period covers all conceptions within the four years preceding March 1996. 


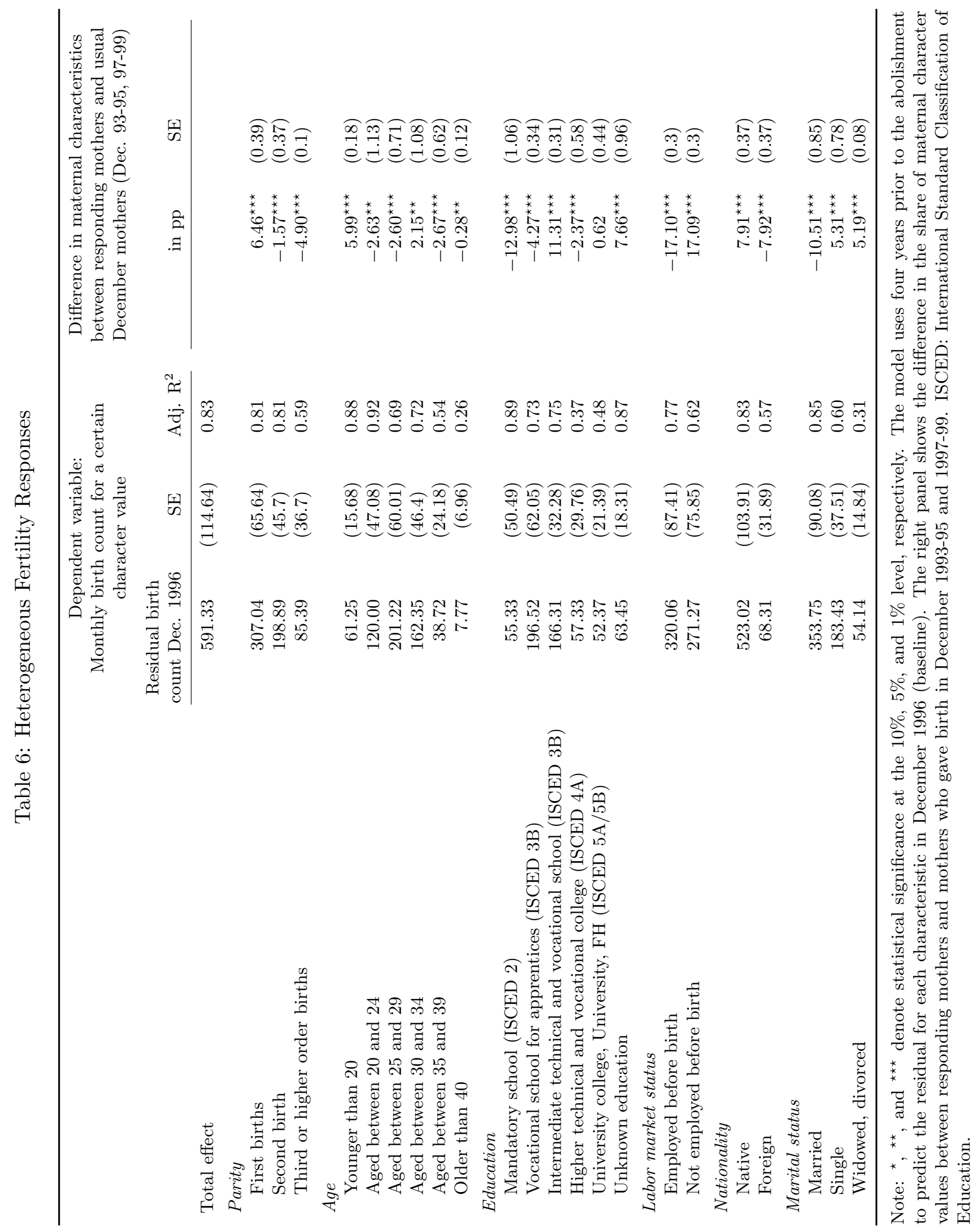


Table 7: Birth Complications

\begin{tabular}{cccccc}
\hline & $\begin{array}{c}\text { Any birth } \\
\text { complication }\end{array}$ & $\begin{array}{c}\text { Vacuum } \\
\text { extraction }\end{array}$ & $\begin{array}{c}\text { Forceps } \\
\text { delivery }\end{array}$ & $\begin{array}{c}\text { Breech } \\
\text { delivery }\end{array}$ & $\begin{array}{c}\text { Cesarean } \\
\text { section }\end{array}$ \\
\cline { 2 - 3 } \cline { 5 - 6 } Percentage share of births & & & & & \\
Residual December 1996 & $0.924^{\star \star \star}$ & $0.463^{\star \star}$ & 0.114 & $0.347^{\star \star \star}$ & 0.061 \\
& $(0.260)$ & $(0.218)$ & $(0.093)$ & $(0.088)$ & $(0.517)$ \\
Share December 1996 & 6.778 & 4.282 & 1.274 & 1.222 & 13.740 \\
Number of observations & 130 & 130 & 130 & 130 & 130 \\
Adjusted R-Squared & 0.321 & 0.799 & 0.914 & 0.896 & 0.982 \\
p-value (F-statistic) & 0.000 & 0.000 & 0.000 & 0.000 & 0.000 \\
\hline
\end{tabular}

Note: ${ }^{\star},{ }^{\star \star}$, and ${ }^{\star \star \star}$ denote statistical significance at the $10 \%, 5 \%$, and $1 \%$ level, respectively. The dependent variable in column 2 is the overall percentage share of birth complications (corresponding to the sum of columns 3 to 5), while columns 3 to 6 show the estimated impact on single delivery methods. The underlying sample period covers observations within the interval from 1995.1 to 1996.10 as well as the interval from 1998.1 to 2006.12. The time trend is assumed to follow a fourth-order polynomial, and a dummy variable for each major policy change within this period is included (1997.1, 2000.7, 2002.1). 
Table 8: Newborns' Health

\begin{tabular}{lcccc}
\hline & $\begin{array}{c}\text { Poor health } \\
(\text { apgar }<7)\end{array}$ & $\begin{array}{c}\text { Small birth } \\
\text { length } \\
(<45 \mathrm{~cm})\end{array}$ & $\begin{array}{c}\text { Low birth } \\
\text { weight } \\
(<2500 \mathrm{~g})\end{array}$ & $\begin{array}{c}\text { Premature } \\
\text { birth } \\
(<37 \text { weeks })\end{array}$ \\
\cline { 2 - 5 } Percentage share of births & -0.081 & -0.227 & -0.603 & -0.444 \\
Residual December 1996 & $(0.14)$ & $(0.225)$ & $(0.321)$ & $(0.321)$ \\
Share December (March) 1996 & 1.352 & 2.522 & 5.713 & 5.254 \\
Number of observations & 83 & 83 & 83 & 83 \\
Adjusted R-Squared & 0.247 & 0.534 & 0.637 & 0.766 \\
p-value (F-statistic) & 0.000 & 0.000 & 0.000 & 0.000 \\
\hline
\end{tabular}

Note: ${ }^{\star},{ }^{\star \star}$, and ${ }^{\star \star \star}$ denote statistical significance at the $10 \%, 5 \%$, and $1 \%$ level, respectively. The dependent variable is the percentage share of newborn children that are in poor health (indicated by a low apgar score), of small birth length, of low birth weight or born prematurely. The sample period in each case covers the four years prior to the abolishment of the baby bonus. 
Figure 1: Actual and De-trended Number of Monthly Births

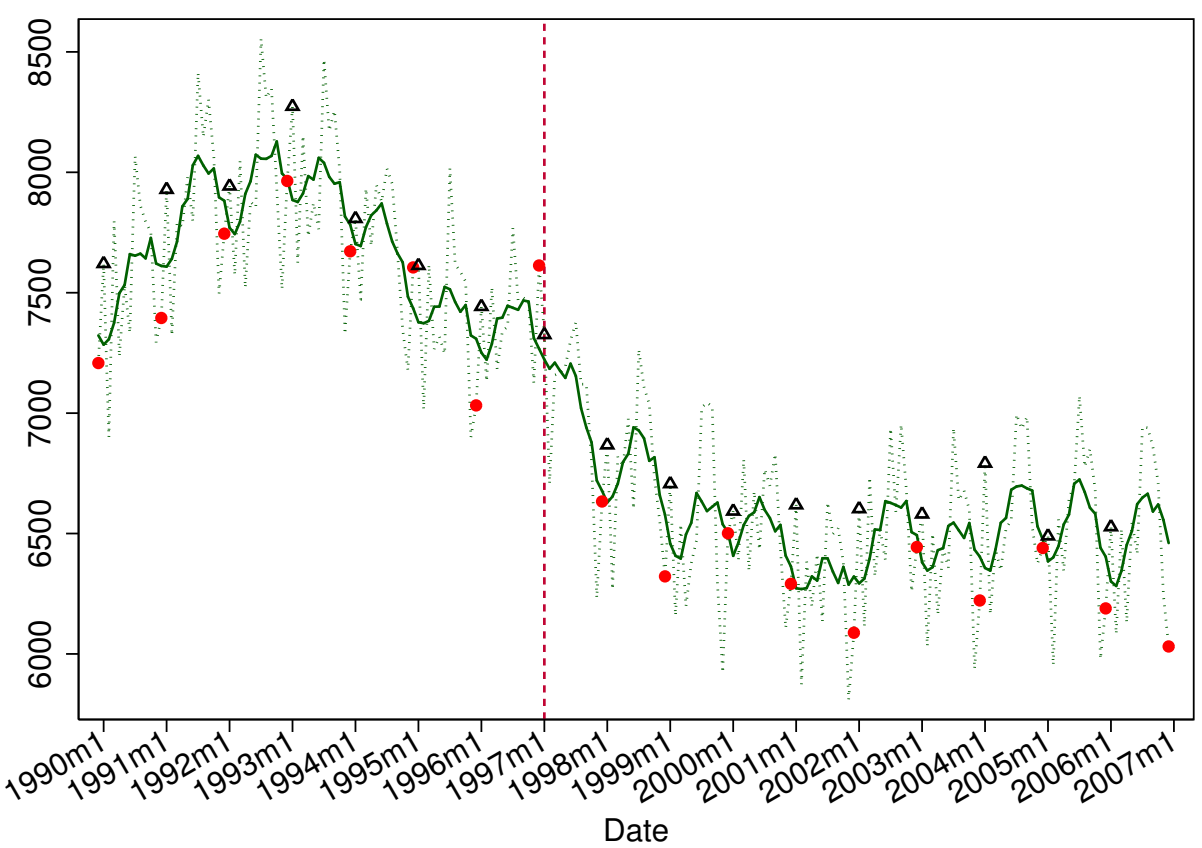

(a) Observed absolute number of monthly births

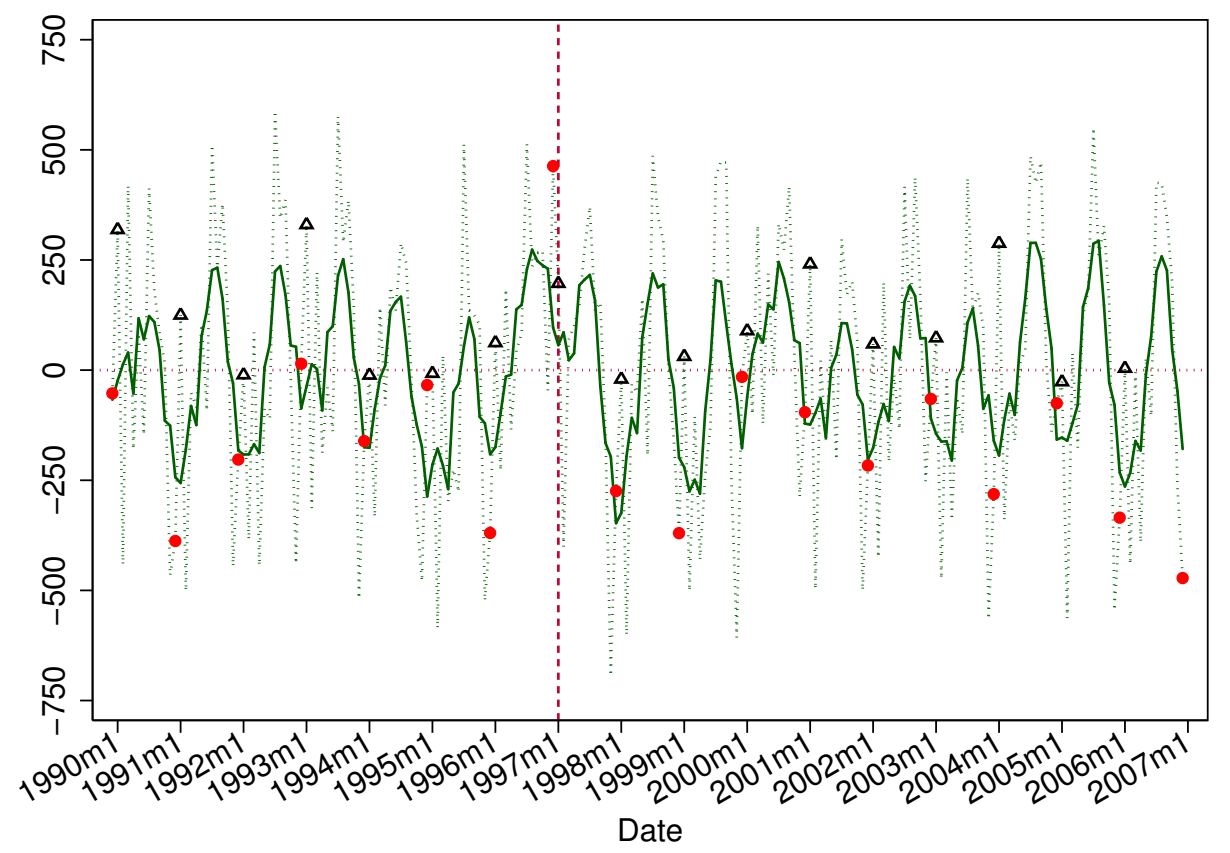

(b) De-trended number of monthly births

Notes: Panel (a) shows the observed number of monthly births. The dotted line shows the actual number of monthly births, the solid line displays the three-month moving average (we average over the current observation as well as three lags and leads). Panel (b) shows the de-trended number of monthly births (de-trending is done using a Hodrick-Prescott filter with default smoothing parameter). The solid line represents the two-month moving average. The dots (triangles) indicate the actual or de-trended number of births in December (January) of each year. 


\section{A Decomposing the Increase in Birth Complications}

To explore whether the increase in birth complications is due to unobserved stress or due to selection, we perform a simple regression-based decomposition analysis (Blinder, 1973; Oaxaca, 1973). The goal of this exercise is to determine the impact of selective fertility responses on the likelihood of some birth complication. For the decomposition analysis we simply compare mothers who gave birth in December 1996 with mothers who gave birth in December 1995 . Table A.1 shows the results (the two columns differ in the weighting scheme used for the decomposition).

Table A.1

In line with the corresponding results from table 7, the upper part of table A.1 documents a difference in the likelihood of experiencing some birth complication of about one percentage point (in table A.1, however, the difference is not statistically significant). The lower part of the table shows the decomposition results, revealing that about $11 \%$ to $13 \%$ of the observed difference in the probability of some birth complication is explained by differences in observed maternal characteristics between the two groups of mothers. Accordingly, as much as $87 \%$ to $89 \%$ of the difference remains unexplained.

Whether the unexplained part is driven by the additional stress from the mistiming of births depends on whether the included variables describe maternal characteristics comprehensively. If not, the decomposition is biased. More specifically, if the omitted variables are correlated with responsiveness to the incentive and therefore with group affiliation, then the unexplained part might capture not only stress, but also other unobserved group differences. ${ }^{27}$

\footnotetext{
${ }^{27}$ In particular, we could think of the following scenario: If responding mothers are of poorer health than average mothers and poorer health (which is not observed) is positively correlated with the probability for labor complications, then the unexplained part of the differential would be upward biased and therefore not only capture the "stress effect". A second issue is whether the included characteristics are affected by the "stress effect" themselves (which seems unlikely in our setup).
} 
Table A.1: Oaxaca-Blinder Decomposition

\begin{tabular}{lcc}
\hline Dependent variable & \multicolumn{2}{c}{ Birth complication } \\
\cline { 2 - 3 } Differential & & \\
Prediction December 1996 & $0.0736^{\star \star \star}$ & $0.0736^{\star \star \star}$ \\
& $(0.0063)$ & $(0.0063)$ \\
Prediction December 1995 & $0.0633^{\star \star \star}$ & $0.0633^{\star \star \star}$ \\
& $(0.0063)$ & $(0.0063)$ \\
Difference & 0.0104 & 0.0104 \\
& $(0.0069)$ & $(0.0069)$ \\
Decomposition & & \\
Explained & $0.0014^{\star \star}$ & $0.0012^{\star}$ \\
& $(0.0007)$ & $(0.0007)$ \\
Unexplained & {$[13.517 \%]$} & {$[11.359 \%]$} \\
& 0.0090 & 0.0092 \\
Number of observations: December 1996 & $(0.0088)$ & $(0.0090)$ \\
Number of observations: December 1995 & & $7^{\prime} 032$ \\
Weights & $7^{\prime} 613$ & $7^{\prime} 613$ \\
\hline
\end{tabular}

Notes: ${ }^{\star},{ }^{\star \star}$, and ${ }^{\star \star \star}$ denote statistical significance at the $10 \%, 5 \%$, and $1 \%$ level, respectively. The dependent variable is a binary variable for labor complication. Robust standard errors are reported in parentheses. Results are obtained using the twofold decomposition model. The first column uses December 1995 coefficients as reference coefficients while the second column uses December 1996 coefficients as reference. 


\section{B Additional Tables and Figures}

Table B.1: Maternal Characteristics and Birth Procedures

\begin{tabular}{|c|c|c|c|c|c|}
\hline & $\begin{array}{l}\text { Breech } \\
\text { delivery }\end{array}$ & $\begin{array}{l}\text { Forceps } \\
\text { delivery }\end{array}$ & $\begin{array}{l}\text { Vacuum } \\
\text { extraction }\end{array}$ & $\begin{array}{c}\text { Cesarean } \\
\text { section }\end{array}$ & $\begin{array}{l}\text { Overall birth } \\
\text { Complications }\end{array}$ \\
\hline Mean & 0.005 & 0.007 & 0.044 & 0.191 & 0.056 \\
\hline Standard deviation & 0.071 & 0.082 & 0.205 & 0.393 & 0.230 \\
\hline Aged between 20 and 24 & $\begin{array}{l}0.001^{\star \star \star} \\
(0.000)\end{array}$ & $\begin{array}{l}0.003^{\star \star \star} \\
(0.000)\end{array}$ & $\begin{array}{l}0.014^{\star \star \star} \\
(0.001)\end{array}$ & $\begin{array}{l}0.033^{\star \star \star} \\
(0.002)\end{array}$ & $\begin{array}{l}0.018^{\star \star \star} \\
(0.001)\end{array}$ \\
\hline Aged between 25 and 29 & $\begin{array}{l}0.002^{\star \star \star} \\
(0.000)\end{array}$ & $\begin{array}{l}0.005^{\star \star \star} \\
(0.000)\end{array}$ & $\begin{array}{l}0.023^{\star \star \star} \\
(0.001)\end{array}$ & $\begin{array}{l}0.067^{\star \star \star} \\
(0.002)\end{array}$ & $\begin{array}{l}0.029^{\star \star \star} \\
(0.001)\end{array}$ \\
\hline Aged between 30 and 34 & $\begin{array}{l}0.001^{\star \star} \\
(0.000)\end{array}$ & $\begin{array}{l}0.005^{\star \star \star} \\
(0.000)\end{array}$ & $\begin{array}{l}0.027^{\star \star \star} \\
(0.001)\end{array}$ & $\begin{array}{l}0.110^{\star \star \star} \\
(0.002)\end{array}$ & $\begin{array}{l}0.033^{\star \star \star} \\
(0.001)\end{array}$ \\
\hline Aged between 35 and 39 & $\begin{array}{l}0.000 \\
(0.000)\end{array}$ & $\begin{array}{l}0.006^{\star \star \star} \\
(0.001)\end{array}$ & $\begin{array}{l}0.035^{\star \star \star} \\
(0.001)\end{array}$ & $\begin{array}{l}0.178^{\star \star \star} \\
(0.002)\end{array}$ & $\begin{array}{l}0.041^{\star \star \star} \\
(0.001)\end{array}$ \\
\hline Older than 40 & $\begin{array}{c}-0.000 \\
(0.001)\end{array}$ & $\begin{array}{l}0.006^{\star \star \star} \\
(0.001)\end{array}$ & $\begin{array}{l}0.037^{\star \star \star} \\
(0.002)\end{array}$ & $\begin{array}{l}0.241^{\star \star \star} \\
(0.003)\end{array}$ & $\begin{array}{l}0.043^{\star \star \star} \\
(0.002)\end{array}$ \\
\hline First birth & $\begin{array}{c}-0.003^{\star \star \star} \\
(0.000)\end{array}$ & $\begin{array}{l}0.012^{\star \star \star} \\
(0.000)\end{array}$ & $\begin{array}{l}0.074^{\star \star \star} \\
(0.001)\end{array}$ & $\begin{array}{l}0.114^{\star \star \star} \\
(0.001)\end{array}$ & $\begin{array}{l}0.083^{\star \star \star} \\
(0.001)\end{array}$ \\
\hline Second birth & $\begin{array}{c}-0.002^{\star \star \star} \\
(0.000)\end{array}$ & $\begin{array}{l}0.002^{\star \star \star} \\
(0.000)\end{array}$ & $\begin{array}{l}0.014^{\star \star \star} \\
(0.001)\end{array}$ & $\begin{array}{l}0.052^{\star \star \star} \\
(0.001)\end{array}$ & $\begin{array}{l}0.013^{\star \star \star} \\
(0.001)\end{array}$ \\
\hline Age at first birth & $\begin{array}{c}0.001^{\star} \\
(0.000)\end{array}$ & $\begin{array}{l}0.002^{\star \star \star} \\
(0.000)\end{array}$ & $\begin{array}{l}0.011^{\star \star \star} \\
(0.001)\end{array}$ & $\begin{array}{l}0.016^{\star \star \star} \\
(0.002)\end{array}$ & $\begin{array}{l}0.014^{\star \star \star} \\
(0.001)\end{array}$ \\
\hline Married & $\begin{array}{l}0.001^{\star \star \star} \\
(0.000)\end{array}$ & $\begin{array}{l}0.001^{\star \star \star} \\
(0.000)\end{array}$ & $\begin{array}{c}0.001 \\
(0.000)\end{array}$ & $\begin{array}{c}-0.005^{\star \star \star} \\
(0.001)\end{array}$ & $\begin{array}{l}0.002^{\star \star \star} \\
(0.001)\end{array}$ \\
\hline Widowed, divorced & $\begin{array}{c}-0.000 \\
(0.000)\end{array}$ & $\begin{array}{c}0.000 \\
(0.000)\end{array}$ & $\begin{array}{c}-0.002^{\star \star} \\
(0.001)\end{array}$ & $\begin{array}{l}0.021^{\star \star \star} \\
(0.002)\end{array}$ & $\begin{array}{r}-0.002^{\star} \\
(0.001)\end{array}$ \\
\hline Native & $\begin{array}{l}0.001^{\star \star \star} \\
(0.000)\end{array}$ & $\begin{array}{c}-0.002^{\star \star \star} \\
(0.000)\end{array}$ & $\begin{array}{c}-0.007^{\star \star \star} \\
(0.001)\end{array}$ & $\begin{array}{c}-0.005^{\star \star \star} \\
(0.001)\end{array}$ & $\begin{array}{c}-0.007^{\star \star \star} \\
(0.001)\end{array}$ \\
\hline Vocational school for apprentices & $\begin{array}{l}-0.001^{\star \star \star} \\
(0.000)\end{array}$ & $\begin{array}{l}0.001^{\star \star \star} \\
(0.000)\end{array}$ & $\begin{array}{c}-0.002^{\star \star \star} \\
(0.001)\end{array}$ & $\begin{array}{c}0.001 \\
(0.001)\end{array}$ & $\begin{array}{c}-0.002^{\star \star \star} \\
(0.001)\end{array}$ \\
\hline $\begin{array}{l}\text { Intermediate technical and } \\
\text { vocational school }\end{array}$ & $\begin{array}{r}-0.000^{\star} \\
(0.000)\end{array}$ & $\begin{array}{c}0.000 \\
(0.000)\end{array}$ & $\begin{array}{c}-0.003^{\star \star \star} \\
(0.001)\end{array}$ & $\begin{array}{l}-0.010^{\star \star \star} \\
(0.001)\end{array}$ & $\begin{array}{c}-0.004^{\star \star \star} \\
(0.001)\end{array}$ \\
\hline $\begin{array}{l}\text { Higher technical and vocational } \\
\text { college }\end{array}$ & $\begin{array}{l}-0.001^{\star \star \star} \\
(0.000)\end{array}$ & $\begin{array}{c}0.000 \\
(0.000)\end{array}$ & $\begin{array}{l}-0.008^{\star \star \star} \\
(0.001)\end{array}$ & $\begin{array}{l}-0.016^{\star \star \star} \\
(0.001)\end{array}$ & $\begin{array}{l}-0.009^{\star \star \star} \\
(0.001)\end{array}$ \\
\hline University college, University, FH & $\begin{array}{l}-0.001^{\star \star \star} \\
(0.000)\end{array}$ & $\begin{array}{c}-0.000 \\
(0.000)\end{array}$ & $\begin{array}{l}-0.008^{\star \star \star} \\
(0.001)\end{array}$ & $\begin{array}{l}-0.013^{\star \star \star} \\
(0.002)\end{array}$ & $\begin{array}{l}-0.009^{\star \star \star} \\
(0.001)\end{array}$ \\
\hline Unknown education & $\begin{array}{l}-0.002^{\star \star \star} \\
(0.000)\end{array}$ & $\begin{array}{l}0.006^{\star \star \star} \\
(0.000)\end{array}$ & $\begin{array}{l}-0.016^{\star \star \star} \\
(0.001)\end{array}$ & $\begin{array}{l}0.013^{\star \star \star} \\
(0.002)\end{array}$ & $\begin{array}{l}-0.012^{\star \star \star} \\
(0.001)\end{array}$ \\
\hline Not employed before birth & $\begin{array}{l}-0.000^{\star \star \star} \\
(0.000)\end{array}$ & $\begin{array}{l}-0.001^{\star \star \star} \\
(0.000)\end{array}$ & $\begin{array}{c}-0.000 \\
(0.000)\end{array}$ & $\begin{array}{l}0.051^{\star \star \star} \\
(0.001)\end{array}$ & $\begin{array}{l}-0.002^{\star \star \star} \\
(0.000)\end{array}$ \\
\hline & $1,042,446$ & $1,042,446$ & $1,042,446$ & $1,042,446$ & $1,042,446$ \\
\hline & 0.000 & 0.004 & 0.024 & 0.026 & 0.025 \\
\hline p-value (F-statistic) & 0.000 & 0.000 & 0.000 & 0.000 & 0.000 \\
\hline
\end{tabular}

Note: ${ }^{\star},{ }^{\star \star}$, and ${ }^{\star \star \star}$ denote statistical significance at the $10 \%, 5 \%$, and $1 \%$ level, respectively. The dependent variable is a dummy variable which takes on the value one if a certain instrumental delivery method has been applied and zero otherwise. The dependent variable in column (5) is one if one of the instrumental vaginal delivery methods (breech delivery, forceps delivery or vacuum extraction) is applied and zero otherwise. Robust standard errors are given in parentheses. 
Table B.2: Impact on Birth Procedures, Robustness Checks

\begin{tabular}{|c|c|c|c|c|c|}
\hline & $\begin{array}{l}\text { All birth } \\
\text { complications }\end{array}$ & $\begin{array}{l}\text { Vacuum } \\
\text { extraction }\end{array}$ & $\begin{array}{l}\text { Forceps } \\
\text { delivery }\end{array}$ & $\begin{array}{l}\text { Breech } \\
\text { delivery }\end{array}$ & $\begin{array}{l}\text { Cesarean } \\
\text { section }\end{array}$ \\
\hline \multicolumn{6}{|l|}{ Panel $A$} \\
\hline $\begin{array}{l}\text { Percentage share of births } \\
\quad \text { Residual December } 1996\end{array}$ & $\begin{array}{l}1.004^{\star \star \star} \\
(0.257)\end{array}$ & $\begin{array}{l}0.490^{\star \star} \\
(0.214)\end{array}$ & $\begin{array}{r}0.143^{\star} \\
(0.087)\end{array}$ & $\begin{array}{l}0.370^{\star \star \star} \\
(0.087)\end{array}$ & $\begin{array}{c}0.038 \\
(0.520)\end{array}$ \\
\hline $\begin{array}{l}\text { Share December } 1996 \\
\text { Number of observations } \\
\text { Adjusted R-Squared } \\
\text { p-value (F-statistic) }\end{array}$ & $\begin{array}{l}6.778 \\
118 \\
0.299 \\
0.000\end{array}$ & $\begin{array}{l}4.282 \\
118 \\
0.807 \\
0.000\end{array}$ & $\begin{array}{l}1.274 \\
118 \\
0.923 \\
0.000\end{array}$ & $\begin{array}{l}1.222 \\
118 \\
0.897 \\
0.000\end{array}$ & $\begin{array}{l}13.740 \\
118 \\
0.981 \\
0.000\end{array}$ \\
\hline \multicolumn{6}{|l|}{ Panel B } \\
\hline $\begin{array}{l}\text { Percentage share of births } \\
\text { Residual December } 1996\end{array}$ & $\begin{array}{l}0.993^{\star \star \star} \\
(0.252)\end{array}$ & $\begin{array}{l}0.442^{\star \star} \\
(0.208)\end{array}$ & $\begin{array}{l}0.182^{\star \star} \\
(0.087)\end{array}$ & $\begin{array}{l}0.369^{\star \star \star} \\
(0.085)\end{array}$ & $\begin{array}{r}-0.093 \\
(0.502)\end{array}$ \\
\hline $\begin{array}{l}\text { Share December } 1996 \\
\text { Number of observations } \\
\text { Adjusted R-Squared } \\
\text { p-value (F-statistic) }\end{array}$ & $\begin{array}{l}6.778 \\
106 \\
0.266 \\
0.000\end{array}$ & $\begin{array}{l}4.282 \\
106 \\
0.819 \\
0.000\end{array}$ & $\begin{array}{l}1.274 \\
106 \\
0.916 \\
0.000\end{array}$ & $\begin{array}{l}1.222 \\
106 \\
0.903 \\
0.000\end{array}$ & $\begin{array}{l}13.740 \\
106 \\
0.982 \\
0.000\end{array}$ \\
\hline
\end{tabular}

Note: ${ }^{\star},{ }^{\star \star}$, and ${ }^{\star \star \star}$ denote statistical significance at the $10 \%, 5 \%$, and $1 \%$ level, respectively. The dependent variable in column 2 is the share of labor complications. Columns 3 to 6 show the effect by single delivery method. Panel A allows the policy change to affect the mix of birth procedures over a period of two years and therefore leaves out two years following the abolishment (i.e. (1995.1-1996.10) and (1999.1-2006.12)). Panel B even leaves out three years (i.e. (1995.1-1996.10) and (2000.1-2006.12)). The time trend is assumed to follow a fourth-order polynomial, and a dummy variable for each major policy change within this period is included (1997.1, 2000.7, 2002.1). 
Table B.3: Maternal Characteristics, Birth Procedure, and Child's Health

\begin{tabular}{|c|c|c|c|c|}
\hline & Poor health & Small birth & Low birth weight & Premature birth \\
\hline Mean & 0.013 & 0.030 & 0.065 & 0.061 \\
\hline Standard deviation & 0.115 & 0.170 & 0.246 & 0.239 \\
\hline Aged between 20 and 24 & $\begin{array}{c}-0.001^{\star \star} \\
(0.001)\end{array}$ & $\begin{array}{c}-0.006^{\star \star \star} \\
(0.001)\end{array}$ & $\begin{array}{c}-0.007^{\star \star \star} \\
(0.001)\end{array}$ & $\begin{array}{c}-0.007^{\star \star \star} \\
(0.001)\end{array}$ \\
\hline Aged between 25 and 29 & $\begin{array}{l}-0.002^{\star \star \star} \\
(0.001)\end{array}$ & $\begin{array}{l}-0.007^{\star \star \star} \\
(0.001)\end{array}$ & $\begin{array}{l}-0.010^{\star \star \star} \\
(0.001)\end{array}$ & $\begin{array}{l}-0.008^{\star \star \star} \\
(0.001)\end{array}$ \\
\hline Aged between 30 and 34 & $\begin{array}{l}-0.002^{\star \star \star} \\
(0.001)\end{array}$ & $\begin{array}{l}-0.007^{\star \star \star} \\
(0.001)\end{array}$ & $\begin{array}{l}-0.009^{\star \star \star} \\
(0.001)\end{array}$ & $\begin{array}{l}-0.008^{\star \star \star} \\
(0.001)\end{array}$ \\
\hline Aged between 35 and 39 & $\begin{array}{c}-0.001 \\
(0.001)\end{array}$ & $\begin{array}{l}-0.003^{\star \star \star} \\
(0.001)\end{array}$ & $\begin{array}{c}0.001 \\
(0.001)\end{array}$ & $\begin{array}{c}0.001 \\
(0.001)\end{array}$ \\
\hline Aged $40+$ & $\begin{array}{l}0.002^{\star \star} \\
(0.001)\end{array}$ & $\begin{array}{l}-0.003^{\star \star} \\
(0.001)\end{array}$ & $\begin{array}{c}0.003 \\
(0.002)\end{array}$ & $\begin{array}{l}0.006^{\star \star \star} \\
(0.002)\end{array}$ \\
\hline First birth & $\begin{array}{l}-0.001^{\star \star \star} \\
(0.000)\end{array}$ & $\begin{array}{l}-0.007^{\star \star \star} \\
(0.001)\end{array}$ & $\begin{array}{l}-0.007^{\star \star \star} \\
(0.001)\end{array}$ & $\begin{array}{l}-0.013^{\star \star \star} \\
(0.001)\end{array}$ \\
\hline Second birth & $\begin{array}{l}-0.002^{\star \star \star} \\
(0.000)\end{array}$ & $\begin{array}{l}-0.005^{\star \star \star} \\
(0.000)\end{array}$ & $\begin{array}{l}-0.011^{\star \star \star} \\
(0.001)\end{array}$ & $\begin{array}{l}-0.014^{\star \star \star} \\
(0.001)\end{array}$ \\
\hline Aged $40+\times$ first birth & $\begin{array}{c}0.000 \\
(0.001)\end{array}$ & $\begin{array}{l}0.005^{\star \star \star} \\
(0.001)\end{array}$ & $\begin{array}{l}0.009^{\star \star \star} \\
(0.001)\end{array}$ & $\begin{array}{l}0.007^{\star \star \star} \\
(0.001)\end{array}$ \\
\hline Married & $\begin{array}{c}-0.000 \\
(0.000)\end{array}$ & $\begin{array}{l}-0.004^{\star \star \star} \\
(0.000)\end{array}$ & $\begin{array}{l}-0.007^{\star \star \star} \\
(0.001)\end{array}$ & $\begin{array}{l}-0.005^{\star \star \star} \\
(0.001)\end{array}$ \\
\hline Widowed or divorced & $\begin{array}{l}0.002^{\star \star \star} \\
(0.001)\end{array}$ & $\begin{array}{l}0.009^{\star \star \star} \\
(0.001)\end{array}$ & $\begin{array}{l}0.015^{\star \star \star} \\
(0.001)\end{array}$ & $\begin{array}{l}0.012^{\star \star \star} \\
(0.001)\end{array}$ \\
\hline Native & $\begin{array}{r}-0.000 \\
(0.000)\end{array}$ & $\begin{array}{l}0.006^{\star \star \star} \\
(0.000)\end{array}$ & $\begin{array}{l}0.017^{\star \star \star} \\
(0.001)\end{array}$ & $\begin{array}{l}0.009^{\star \star \star} \\
(0.001)\end{array}$ \\
\hline Vocational school for apprentices & $\begin{array}{l}-0.003^{\star \star \star} \\
(0.000)\end{array}$ & $\begin{array}{l}-0.004^{\star \star \star} \\
(0.000)\end{array}$ & $\begin{array}{l}-0.006^{\star \star \star} \\
(0.001)\end{array}$ & $\begin{array}{l}-0.004^{\star \star \star} \\
(0.001)\end{array}$ \\
\hline $\begin{array}{l}\text { Intermediate technical and } \\
\text { vocational school }\end{array}$ & $\begin{array}{l}-0.005^{\star \star \star} \\
(0.000)\end{array}$ & $\begin{array}{l}-0.008^{\star \star \star} \\
(0.001)\end{array}$ & $\begin{array}{l}-0.014^{\star \star \star} \\
(0.001)\end{array}$ & $\begin{array}{l}-0.008^{\star \star \star} \\
(0.001)\end{array}$ \\
\hline $\begin{array}{l}\text { Higher technical and vocational } \\
\text { college }\end{array}$ & $\begin{array}{l}-0.007^{\star \star \star} \\
(0.000)\end{array}$ & $\begin{array}{l}-0.011^{\star \star \star} \\
(0.001)\end{array}$ & $\begin{array}{l}-0.020^{\star \star \star} \\
(0.001)\end{array}$ & $\begin{array}{l}-0.013^{\star \star \star} \\
(0.001)\end{array}$ \\
\hline University college, University, FH & $\begin{array}{l}-0.007^{\star \star \star} \\
(0.000)\end{array}$ & $\begin{array}{l}-0.014^{\star \star \star} \\
(0.001)\end{array}$ & $\begin{array}{l}-0.028^{\star \star \star} \\
(0.001)\end{array}$ & $\begin{array}{l}-0.019^{\star \star \star} \\
(0.001)\end{array}$ \\
\hline Unknown education & $\begin{array}{l}-0.002^{\star \star \star} \\
(0.001)\end{array}$ & $\begin{array}{c}-0.001 \\
(0.001)\end{array}$ & $\begin{array}{l}-0.004^{\star \star \star} \\
(0.001)\end{array}$ & $\begin{array}{c}-0.002 \\
(0.001)\end{array}$ \\
\hline Not employed before birth & $\begin{array}{l}0.001^{\star \star \star} \\
(0.000)\end{array}$ & $\begin{array}{l}0.015^{\star \star \star} \\
(0.000)\end{array}$ & $\begin{array}{l}0.027^{\star \star \star} \\
(0.001)\end{array}$ & $\begin{array}{l}0.023^{\star \star \star} \\
(0.000)\end{array}$ \\
\hline Breech delivery & $\begin{array}{l}0.056^{\star \star \star} \\
(0.002)\end{array}$ & $\begin{array}{l}0.044^{\star \star \star} \\
(0.002)\end{array}$ & $\begin{array}{l}0.098^{\star \star \star} \\
(0.003)\end{array}$ & $\begin{array}{l}0.074^{\star \star \star} \\
(0.003)\end{array}$ \\
\hline Forceps delivery & $\begin{array}{l}0.024^{\star \star \star} \\
(0.001)\end{array}$ & $\begin{array}{c}-0.000 \\
(0.002)\end{array}$ & $\begin{array}{c}-0.000 \\
(0.003)\end{array}$ & $\begin{array}{r}-0.005^{\star} \\
(0.003)\end{array}$ \\
\hline Vacuum extraction & $\begin{array}{l}0.014^{\star \star \star} \\
(0.001)\end{array}$ & $\begin{array}{l}-0.006^{\star \star \star} \\
(0.001)\end{array}$ & $\begin{array}{l}-0.011^{\star \star \star} \\
(0.001)\end{array}$ & $\begin{array}{l}-0.012^{\star \star \star} \\
(0.001)\end{array}$ \\
\hline Cesarean section & $\begin{array}{l}0.032^{\star \star \star} \\
(0.000)\end{array}$ & $\begin{array}{l}0.086^{\star \star \star} \\
(0.000)\end{array}$ & $\begin{array}{l}0.142^{\star \star \star} \\
(0.001)\end{array}$ & $\begin{array}{l}0.123^{\star \star \star} \\
(0.001)\end{array}$ \\
\hline Number of observations & $1,042,446$ & $1,042,446$ & $1,042,446$ & $1,042,446$ \\
\hline Adjusted R-Squared & 0.014 & 0.044 & 0.059 & 0.046 \\
\hline p-value (F-statistic) & 0.000 & 0.000 & 0.000 & 0.000 \\
\hline
\end{tabular}

Notes: Notes: ${ }^{\star},{ }^{\star \star}$, and ${ }^{\star \star \star}$ denote statistical significance at the $10 \%, 5 \%$, and $1 \%$ level, respectively 